\title{
From "Table 29" to the actuarial balance sheet: is it really that big a leap?
}

\author{
Anne M. Garvey
}

Department of Economics and Management Sciences, University of Alcalá, Madrid (Spain);

Juan Manuel Pérez-Salamero González

Department of Financial Economics and Actuarial Science, University of Valencia, Valencia. (Spain)

Manuel Ventura-Marco

Department of Financial Economics and Actuarial Science, University of

Valencia, Valencia. (Spain)

Carlos Vidal-Meliá

Department of Financial Economics and Actuarial Science, University of Valencia

Instituto Complutense
de
Análisis Económico

\begin{abstract}
EU regulations since 2017 have required all Member States to disclose their accrued-todate pension liabilities (ADL) using a standard actuarial cost method and some common assumptions. This applies to both Social Security (SS) schemes and unfunded defined benefit (DB) schemes covering civil servants. These pension liabilities have to be disclosed in a supplementary table referred to as Table 29. An actuarial balance sheet (ABS) can be defined as a financial statement that lists a pension system's obligations to contributors and pensioners at a particular date, together with the amounts of the assets (financial and in particular those from contributions) that underwrite those commitments. The ABS can be used to assess the solvency of SS schemes, whereas Table 29 cannot. This paper develops a methodology to (easily) transform Table 29 into an ABS and compile its associated income statement (IS). To enable policymakers to better understand how the model would function, the paper also contains a country case study based on data from the most recently published Table 29 for Spain. According to our best estimate assumptions, it can be said that the Spanish pension system is partially insolvent because only part of the pension entitlements is backed up by assets, and that the system's sustainability has markedly deteriorated over the period 2015-2018.
\end{abstract}

Keywords: Accountability, Actuarial Balance Sheet, Pension Liabilities, Social Security, Spain, Table 29, Useful Information,

JEL Classification: G22, H55, H83.

\section{ICAE Working Paper n 2105}

\section{March, 2021}

ISSN: 2341-2356

WEB DE LA COLECCIÓN:

http://www.ucm.es/fundamentos-analisis-economico2/documentos-de-trabajo-del-icae Copyright $\odot 2021$ by ICAE.

Working papers are in draft form and are distributed for discussion. It may not be reproduced without permission of the author/s. 


\title{
From "Table 29" to the actuarial balance sheet: is it really that big a leap?*
}

\author{
Anne M. Garvey ${ }^{\dagger}$, Juan Manuel Pérez-Salamero González ${ }^{\ddagger}$, Manuel Ventura- \\ Marco $^{\S}$, and Carlos Vidal-Meliá ${ }^{* *}$.
}

12 March 2021

\begin{abstract}
EU regulations since 2017 have required all Member States to disclose their accrued-to-date pension liabilities (ADL) using a standard actuarial cost method and some common assumptions. This applies to both Social Security (SS) schemes and unfunded defined benefit (DB) schemes covering civil servants. These pension liabilities have to be disclosed in a supplementary table referred to as Table 29. An actuarial balance sheet (ABS) can be defined as a financial statement that lists a pension system's obligations to contributors and pensioners at a particular date, together with the amounts of the assets (financial and in particular those from contributions) that underwrite those commitments. The ABS can be used to assess the solvency of SS schemes, whereas Table 29 cannot. This paper develops a methodology to (easily) transform Table 29 into an ABS and compile its associated income statement (IS). To enable policymakers to better understand how the model would function, the paper also contains a country case study based on data from the most recently published Table 29 for Spain. According to our best estimate assumptions, it can be said that the Spanish pension system is partially insolvent because only part of the pension entitlements is backed up by assets, and that the system's sustainability has markedly deteriorated over the period 2015-2018.
\end{abstract}

JEL: G22, H55, H83.

KEYWORDS: Accountability, Actuarial Balance Sheet, Pension Liabilities, Social Security, Spain, Table 29, Useful Information,

\footnotetext{
* Funding: Manuel Ventura-Marco and Carlos Vidal-Meliá are grateful for the financial assistance received from the Spanish Ministry of the Economy and Competitiveness (Ministerio de Economía y Competitividad) projects ECO2015-65826-P, RTI2018-097087-B-100 and the Generalitat Valenciana (Valencian Government), project AICO/2019/075. Carlos Vidal-Meliá and Juan Manuel Pérez Salamero Gonzalez also acknowledge the financial support from the Basque Government (Project IT1336-19). Anne M. Garvey is grateful for the financial assistance received from the Spanish Ministry of Science, Innovation and Universities (Ministerio de Ciencia e Inovación y Universidades) project PID2019-105570GB-I00 and the University of Alcalá project $\mathrm{CM} / \mathrm{JIM} / 2019-044$.

Acknowledgements: The authors are especially grateful to Peter Hall for his help with the English text.

t Department of Economics and Management Sciences, University of Alcalá, Madrid (Spain); ORCID Author ID: 0000-0002-5630-9635 anne.garvey@uah.es.

\# Department of Financial Economics and Actuarial Science, University of Valencia, Valencia. (Spain); ORCID Author ID: 0000-0001-7710-4869, juan.perez-salamero@uv.es

$\checkmark$ Department of Financial Economics and Actuarial Science, University of Valencia, Valencia. (Spain); ORCID Author ID: 0000-0002-4510-7499, manuel.ventura@uv.es

** Contact author, Department of Financial Economics and Actuarial Science, University of Valencia (Spain) and research affiliate with the Instituto Complutense de Análisis Económico (ICAE), Complutense University of Madrid (Spain), ORCID Author ID: 0000-0002-7227-5076, carlos.vidal@uv.es
} 


\section{1.-Introduction}

EU regulations since 2017 have required all Member States to disclose their accrued-todate pension liability (ADL) using a standard actuarial cost method and some common assumptions. The information they have to provide applies to both Social Security (SS) schemes and unfunded defined benefit (DB) schemes covering civil servants. These pension liabilities ${ }^{1}$ do not need to be included in the government's core national accounts, but they do have to be disclosed in a supplementary table, known as Table 29. The aim of this supplementary table is to give an overview of the pension obligations (of general government and other institutional sectors) to households covered by any social insurance pension scheme.

The figures presented in Table 29 show the perspective not only of the debtor (the pension scheme) and its pension obligations (either liabilities or contingent liabilities) but also of the creditor (households) and their pension entitlements (either assets or contingent assets) (Eurostat, 2020).

The first Table 29 data transmission took place in December 2017 with 2015 as the reference year. Transmissions occur every three years for data relating to year t-2. Eurostat has published Table 29 statistics on its website since the end of 2018. The second Table 29 data wave is currently being reported, relating to pension liabilities at the end of $2018^{2}$.

The Table 29 pension reporting exercise is based on the ADL method, which is consistent with the closed-group approach (CG). Thus a plan's liabilities are equal to the present value of all expected future benefits to pensioners and all accrued rights of current affiliates. Accrued pension rights derive from social contributions already paid by current workers and the remaining pension entitlements payable to existing pensioners. This methodology may provide relevant information for pension systems financed using a full advance funding method, but it does not allow for the assessment of the financial sustainability of SS schemes, which are typically financed on a pay-as-you-go/partially funded basis.

Large pension entitlements do not necessarily mean unsustainable pension schemes, and small pension entitlements do not necessarily mean that the respective pension schemes are financially stable over the long term (Eurostat, 2020). As Stavrakis (2018) warns, if the ADL figures - which by their very nature are extremely large - are disclosed in isolation without sufficient and proper explanation or even without any complementary information at all, they can easily be misused or misinterpreted by the media and other external users, thus creating an unwarranted negative public opinion or perception of SS schemes.

Wiener and Stokoe (2018) conclude that the use of ADL is problematic. It is not only potentially misleading but may encourage "accounting arbitrage", whereby countries are motivated to structure their systems in certain ways so as to reduce the value given for their pension liabilities. In short, it can be said that the ADL captures only one side of a pension scheme's balance sheet but is nevertheless the most valuable instrument for reporting the system's financial status from an SS administration's point of view (Vidal-Meliá et al., 2018, Garvey et al., 2020; TSPS, 2020).

The aim of this paper is to present a methodology to (easily) transform Table 29 into an actuarial balance sheet (ABS) and compile its associated income statement (IS). The ABS can be defined as a financial statement that details a pension system's obligations to contributors

\footnotetext{
${ }^{1}$ Liabilities are expressed in terms of "actuarial present value" (APV). APV is the sum of money needed now which, invested over the duration of the scheme's pension commitments, is expected to be sufficient to pay out all the pensions promised.

2 https://ec.europa.eu/eurostat/web/pensions/information-member-states.
} 
and pensioners at a particular date, together with the amounts of the assets (financial and in particular those from contributions) that underwrite those commitments.

The underlying idea behind the ABS is that any analysis that looks only at the liabilities of PAYG pension systems while ignoring explicit or implicit assets is misleading (Barr and Diamond, 2009). The ABS can be used to assess the solvency of SS schemes, whereas Table 29 cannot.

It is difficult to understate the real importance of including an IS as part of the published information relating to a country's public pension system. It could improve people's understanding of the information and make the system more transparent. Naturally any change in net worth can be determined by calculating the difference between the opening and closing amounts for this item entered on the balance sheet for the reporting period, but an IS gives a breakdown of that change during the period.

We are convinced that our paper is timely because it is in line with the recommendation made by Goebel (2017) that the national accounts/statistical community should continue to develop additional guidelines and practices to enable statisticians, actuaries and accountants to record more consistent and internationally comparable statistics on SS and other government-sponsored pension schemes.

The idea of transforming the supplementary table for pension entitlements (Table 29) into an ABS and compiling its associated IS has not, to the best of our knowledge, been previously explored. As far as we know this is an innovation and a step forward on the path to improved pension information precisely because it develops the necessary technicalities to compile the ABS and the IS from Table 29. We have found no similar model in the economic literature. The subject could be of particular

interest to policymakers, statisticians, SS actuaries and public finance economists, to name just a few.

The structure of the paper is as follows. After this introduction, Section 2 briefly describes the layout of Table 29. Section 3 presents the main characteristics of a social insurance accounting model containing the actuarial balance sheet (ABS) and its associated income statement (IS) for an SS scheme that includes retirement, disability, survivor contingencies and minimum pension benefits (MPB). Section 4 presents our methodology to (easily) transform Table 29 into an ABS and compile the IS. Section 5 develops a real example based on data from the most recently published Table 29 for Spain. This will help policymakers and others to understand how the model would function. The paper ends with the concluding comments, the references used and two appendices. The first of these is a technical appendix, while the second shows the main results of our methodology for the period 2014-2015 in Spain.

\section{2-. The Supplementary Table (Table 29).}

Pension entitlements were already partly recorded in the 1993 System of National Accounts (SNA). However, the 1993 SNA did not recognize the pension entitlements of defined benefit (unfunded) pension schemes, and therefore neither the assets of households nor the liabilities of such schemes were included.

The SNA of 2008 and the European System of Accounts (ESA) of 2010 are the new statistical standards and provide detailed guidelines for compiling supplementary data on pension entitlements under defined benefit schemes (EC et al., 2009; Eurostat, 2013). They cover schemes managed by non-general government units, those managed by the general government and also SS schemes. According to these international standards, household pension entitlements (and the schemes' pension obligations) are recorded in national 
accounts (NA). However, these standards also define a set of rules that provide instructions with guidance as to when pension schemes should be included in the core system of accounts and when the outstanding amounts of pension entitlements should only be included in the supplementary table for social insurance pension schemes (Table 29, Eurostat, 2020).

Our particular interest is in SS schemes, i.e. contractual insurance plans where affiliates are obliged by the general government to insure against old age and other risks such as disability, orphanhood, widowhood, etc... These schemes cover the entire community, or at least large sections of it, and are imposed, supervised and financed by government units (Eurostat, 2013).

The supplementary table (Table 29) records all positions and flows relating to pension obligations for all social insurance pension schemes, showing all those that correspond to the pension schemes in an economy and (as a counterpart) the pension entitlements held by households.

The Table 29 pension reporting exercise is based on the accrued-to-date liability (ADL) method. This is consistent with the closed-group approach (CG) insofar as it excludes future accruals. In conceptual terms it is similar to a termination reserve in private sector or occupational pension plans, for example. The level of the termination reserve can be regarded as the scheme's full funding level. This amount should therefore equal the resources that in our case would be required to shut down an SS scheme while honouring all past commitments (Holzmann et al., 2001; Kaier and Müller, 2015; Drouin et al., 2018). The ADL concept is appropriate for national accounts purposes and includes the present value of pension entitlements arising from already accrued pension rights.

For the sake of completeness, we include a description of the Table 29 column headings (Table 1) and the rows of the supplementary table (Table 2) (Eurostat, 2013 and 2020; ONS, 2018).

Table 1: Table 29 column headings

\begin{tabular}{|c|c|c|c|c|c|c|c|c|c|c|c|}
\hline Recording & \multicolumn{6}{|c|}{ Core national accounts } & \multicolumn{2}{|c|}{$\begin{array}{c}\text { Not in the core } \\
\text { accounts }\end{array}$} & \multirow{3}{*}{ 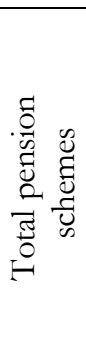 } & \multirow{2}{*}{\multicolumn{2}{|c|}{$\begin{array}{l}\text { Counterparts: } \\
\text { entitlements of }\end{array}$}} \\
\hline $\begin{array}{l}\text { Pension } \\
\text { manager }\end{array}$ & \multicolumn{3}{|c|}{$\begin{array}{l}\text { Non-general } \\
\text { government }\end{array}$} & \multicolumn{5}{|c|}{ General government } & & & \\
\hline & & & & & & & & & & 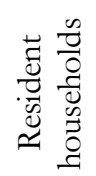 & 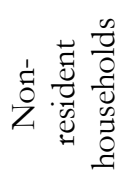 \\
\hline & \multirow[b]{2}{*}{ DC } & \multirow[b]{2}{*}{$\begin{array}{l}\mathrm{DB} \text { and } \\
\text { hybrid } \\
\text { schemes }\end{array}$} & \multirow[b]{2}{*}{ Total } & \multirow[b]{2}{*}{ DC } & \multicolumn{3}{|c|}{$\begin{array}{l}\text { DB schemes for general } \\
\text { government employees }\end{array}$} & \multirow[b]{2}{*}{$\begin{array}{l}\text { Social } \\
\text { Security } \\
\text { pension } \\
\text { schemes }\end{array}$} & & & \\
\hline & & & & & $\begin{array}{l}\text { Classified in } \\
\text { financial } \\
\text { corporations }\end{array}$ & $\begin{array}{l}\text { Classified } \\
\text { in } \\
\text { general } \\
\text { govt }\end{array}$ & $\begin{array}{l}\text { Classified } \\
\text { in } \\
\text { general } \\
\text { govt }\end{array}$ & & & & \\
\hline & $\mathbf{A}$ & $\mathbf{B}$ & $\mathrm{C}$ & $\mathbf{D}$ & $\mathrm{E}$ & $\mathrm{F}$ & $\mathbf{G}$ & $\mathbf{H}$ & $\mathrm{I}$ & $\mathrm{J}$ & $\mathbf{K}$ \\
\hline \multicolumn{12}{|c|}{ Source: Eurostat (2013) } \\
\hline
\end{tabular}

The main part of Table 29 is composed of Columns A to I. An additional Eurostat requirement for 2015 was to split pension entitlements according to whether they belong to resident or non-resident households (Columns J and $\mathbf{K}$ ).

Table 29 starts by categorizing pensions according to where they are recorded, i.e. in the core national accounts or "not in the core national accounts" (only in Table 29). This is shown in the first row of column headings for Columns A to $\mathbf{H}$. The understanding in the EU is that the liabilities of unfunded pension schemes for government employees and unfunded SS 
pension schemes need to be recorded only in Table 29 (not in the core accounts). Funded schemes, on the other hand, must be recorded in the core accounts.

The second important division in the main part of the table (Columns A to I) is between those pension schemes for which the general government sector of the national accounts is the pension manager ${ }^{3}$ and those for which the pension manager information is not in the core accounts.

The next row of column headings relates to the type of pension scheme. Workplace pension schemes are in Columns A to $\mathbf{G}$ and $\mathbf{S S}$ schemes are in Column H. Workplace schemes are further divided according to whether they are defined benefit (DB) or defined contribution (DC) and which sector of the national accounts is used to categorize the scheme administrator - which might not be the same sector as the pension manager.

Table 2 below shows the rows that relate to balance sheet positions, transactions and other flows associated with the pension entitlements of the schemes included in the supplementary table. There is a reconciliation between the opening stock of pension entitlements of such schemes at the beginning of a period and the closing stock of pension entitlements at the end of a period, which takes into account all the transactions and other flows during the period.

For schemes recorded in Columns $\mathbf{G}$ and $\mathbf{H}$, the stocks of pension entitlements are not recorded in the core national accounts. However, many of the transactions related to contribution income and pension expenses are already recorded in the core national accounts.

\section{Opening and closing balance sheets}

Row 1 shows the opening stock of pension entitlements, which is exactly equivalent to the closing stock of the previous accounting period.

Row 10 shows the corresponding closing stock of pension entitlements at the end of the accounting period.

\section{Changes in pension entitlements due to transactions (Rows 2-7)}

Employer and employee actual social contributions are recorded in Rows 2.1 and 2.3, as is the case in the core national accounts. In some pension schemes, notably SS schemes, a distinction needs to be made between actual social contributions relating to pensions from social contributions and other pensions relating to other social risks such as unemployment.

For DB pension schemes, the employers' imputed social contributions could be measured as the balancing item, insofar as any changes in entitlements over the year that are not included in other rows of the table are captured in Row 2.2. This row covers "experience effects", where the observed outcome of pension modelling assumptions (wage growth rate, inflation rate and discount rate) differs from the levels assumed. Zeros are shown in this row for DC schemes.

Alternatively, the employers' imputed social contributions in Row 2.2 could be actuarially calculated as the difference between the current service cost ${ }^{4}$ in a given year and the sum of

\footnotetext{
3 The concept of pension manager refers to the organization that is ultimately responsible for the pension obligations. General government in the context of national accounts is broadly similar to the lay person's definition of government, while "non-general government" pension managers may be private sector employers, multi-employer pension funds or insurance companies that provide pensions. Any public sector organizations, such as public corporations where the government is deemed not to be responsible for the pension liabilities, are classified as non-general government when referring to the pension manager.

${ }^{4}$ According to IFRS (2011), the current service cost is the increase in the present value of the defined benefit obligation resulting from employee service in the current period. Past service cost would be the change in the
} 
the employee and employer social contributions paid in that year plus the experience effect that reflects the assumptions made to calculate the opening stock of pension entitlements and the actual experience.

Table 2: Rows of the supplementary table showing accrued-to-date pension entitlements in social insurance

\begin{tabular}{|c|c|}
\hline Row No. & Item \\
\hline 1 & $\begin{array}{l}\text { Pension entitlements at } 31 \text { December } t \\
\text { (Opening Balance Sheet) }\end{array}$ \\
\hline $\begin{array}{c}2 \\
(2.1+2.2+2.3+2.4-2.5)\end{array}$ & Increase in pension entitlements due to social contributions \\
\hline 2.1 & Employer actual social contributions \\
\hline 2.2 & Employer imputed social contributions \\
\hline 2.3 & Household actual social contributions \\
\hline 2.4 & Household social contribution supplements \\
\hline 2.5 & Less: pension scheme service charges \\
\hline 3 & $\begin{array}{l}\text { Other (actuarial) changes in pension entitlements in social } \\
\text { security pension schemes }\end{array}$ \\
\hline 4 & $\begin{array}{c}\begin{array}{c}\text { Reduction in pension entitlements due to payment of pension } \\
\text { benefits }\end{array} \\
\text { (n) }\end{array}$ \\
\hline $\begin{array}{c}5 \\
(2+3-4)\end{array}$ & $\begin{array}{l}\text { Changes in pension entitlements due to social contributions and } \\
\text { pension benefits }\end{array}$ \\
\hline 6 & Transfers of pension entitlements between schemes \\
\hline 7 & $\begin{array}{l}\text { Change in entitlements due to negotiated changes in scheme } \\
\text { structure }\end{array}$ \\
\hline $8+9$ & $\begin{array}{l}\begin{array}{l}\text { Changes in entitlements due to revaluations and other changes in } \\
\text { volume }\end{array} \\
\end{array}$ \\
\hline 8 & Changes in entitlements due to revaluations \\
\hline 9 & Changes in entitlements due to other changes in volume \\
\hline $\begin{array}{c}10 \\
(1+5+6+7+8+9)\end{array}$ & $\begin{array}{l}\text { Pension entitlements at } 31 \text { December } t+1 \\
\text { (Closing Balance Sheet) }\end{array}$ \\
\hline & Source: Eurostat (2013) \\
\hline
\end{tabular}

Row 2.4 shows the property income earned or imputed in the schemes, which is routed via the household sector or the rest of the world sector. It should be noted that for all DB schemes including social security, whether funded or unfunded, this property income is equal to the discount rate multiplied by the pension entitlements at the beginning of the accounting period.

Some of the entries for the rows in Columns $\mathrm{G}$ and $\mathrm{H}$ - specifically the actual contributions made by both employers and employees - appear in the core national accounts, even though the entitlements and changes in entitlements do not. Other entries in Columns $\mathrm{G}$ and $\mathrm{H}$ are only shown in the supplementary table.

An item calculated on the same actuarial basis in respect of social security is shown in Row 3 as "other (actuarial) changes in pension entitlements in social security pension schemes". It can thus be distinguished from the employers' imputed social contributions.

Row 3 represents the difference between the current service cost in a given year and the sum of the employees' and employer's actual social contributions paid during that year. It also captures any "experience effects" observed for SS pension schemes where the observed

present value of the defined benefit obligation for employee service in previous periods resulting from a plan amendment (when a defined benefit plan is introduced, withdrawn or changed) or a curtailment (when the entity significantly reduces the number of employees covered by a plan). 
outcome of the pension modelling assumptions for that year (wage growth rate, inflation rate and discount rate) differs from the levels assumed.

The entries in this row can be positive or negative. Negative cases occur in an SS pension scheme when the discount rate is higher than the scheme's internal rate of return (IRR). A pension scheme's IRR is the discount rate that equalizes the present value of the actual contributions paid and the discounted value of the pension entitlements accrued through those contributions. Negative entries occur when, for example, contributions have been raised above the required actuarial level in order to finance a short-term cash shortfall.

Row 4 shows the pension benefits that are paid during the accounting period. This has the effect of "settling" some of the pension entitlements included in the opening stock in Row 1.

Row 5 presents the changes in pension entitlements due to contributions and benefits. It is Row 2 plus Row 3 minus Row 4.

When one unit takes over responsibility for pension entitlements from another unit, this is recorded in Row $\mathbf{6}$ as the transfer of pension entitlements from the original pension scheme to the new pension scheme. There may also be an underlying transfer in cash or other financial assets to compensate the new pension scheme, and it is possible that the value of the financial assets transferred is not exactly equal to the value of the pension entitlements transferred. However, Row 6 only relates to the transfer of entitlements between schemes.

Row 7 shows the impact of any reforms to pension scheme structures on entitlements relating to past service.

\section{Changes to pension entitlements due to other economic flows}

Rows 8 and 9 account for other flows such as revaluations and other changes in volume associated with pension schemes in social insurance.

Revaluations come about due to changes in key model assumptions in the actuarial calculations. These assumptions are the discount rate, the wage rate and the inflation rate.

Experience effects are not included here unless they cannot be identified separately. Other changes in actuarial estimates are more likely to be recorded as other changes in the volume of assets. The effects of price changes stemming from the investment of the entitlements are recorded as revaluations and appear in the revaluation account.

When the demographic assumptions used in the actuarial calculations are changed, they are recorded as other changes in the volume of assets.

To conclude these brief comments on Table 29, it should be mentioned that further detailed explanations on how to complete it can be found in the papers by Müller and Raffelhüschen (2014) for Latvia, Schmitz et al. (2015) for the Netherlands, Brys (2017) for Belgium and the INE (2020) for Spain, to name just a few.

Although the introduction to Table 29 is a valuable first step in reporting pension liabilities, its actual usefulness for policymakers and stakeholders is in doubt.

As mentioned in the introduction, it is important to stress that pension entitlements do not allow any conclusions to be drawn as to the financial sustainability of a pension scheme. Large pension entitlements do not necessarily mean unsustainable pension schemes, and small pension entitlements do not mean that the respective pension schemes are financially stable in the long term (Eurostat, 2020).

For Blanchet et al., (2017), ADL figures remain poorly informative regarding the contribution of reforms aimed at restoring pension sustainability. The information they provide is clearly 
more relevant when looked at from the point of view of households as indicators of prospective pension entitlements. Such information is much more interesting at the micro level than at the macro level.

Wiener and Stokoe (2018) conclude that the use of the ADL method is not without problems. It could encourage countries to use other systemic structures so as to avoid revealing the full size of their pension liabilities, and this could give rise to misleading information.

In addition, the information shown in Table 29 is fairly incomplete insofar as a breakdown of liabilities between contributors and pensioners is not presented. The division of the liability according to the different contingencies covered - retirement, permanent disability or other contingencies - is not reported. The separation of the liabilities that derive from contributory and non-contributory rights is also missing. And last but not least, since Table 29 does not show any solvency or sustainability indicator, pensioners and especially contributors have no information regarding the probability that they will receive their future benefits.

\section{3.-The accounting model: the actuarial balance sheet and the income statement.}

As far as measuring the liabilities and assets of SS schemes is concerned, we can find five approaches in the specialized literature, four of which are reasonably well-known - closed group without future accruals (CG), closed group with future accruals (CGFA), hybrid open group (HOG) and open group (OG) (Holzmann et al., 2001; Kaier and Müller, 2015; Drouin et al., 2018) - while the fifth is relatively unknown even among most pension experts: the "Swedish" open group (SOG).

Our model follows the SOG approach, which has been used by the Swedish authorities to measure the assets and liabilities of an SS scheme since 2001 (TSPS, 2002).

The SOG is based on the CG method but modified to make it equivalent to OG. It can be considered "open group" in any particular year $t$ because, in order to value the system's assets and liabilities, it takes new entrants into account and assumes that there will be contributions to meet liabilities, although the valuation formulas consider pensioners and contributors only at the valuation date (Ventura and Vidal-Meliá, 2014; Vidal-Meliá et al., 2018; Metzger, 2019; Garvey et al., 2020).

One of the central accounting principles of this approach is that the system's assets and liabilities are valued on the basis of events and transactions that are verifiable at the time of valuation, with no need for explicit projections. It is assumed that the system's rules and the economic and demographic conditions prevailing at the time of the valuation remain constant (TSPS, 2020).

This way of measuring the system's assets and liabilities has a high degree of transparency and needs no complicated projections of economic, financial or demographic variables that could easily have a bias effect on the sustainability and solvency indicators. It is suitable for the introduction of automatic balance mechanisms (ABMs), given that possibly endless debates about the accuracy of long-term projections are avoided.

As mentioned earlier, the ABS can be defined as a financial statement that lists a pension system's obligations to contributors and pensioners at a particular date, along with the amounts of the various assets (financial and in particular those from contributions) that underwrite those commitments. The main aim of the ABS is to give a true and fair view of the pension system's assets and liabilities at the beginning and end of the accounting year and, by comparing these figures, to determine the change in its net worth. The pension 
system is said to be solvent at the valuation date when the ratio between its assets and liabilities is equal to or greater than 1 .

An ABS for a fictional already-functioning SS scheme can be compiled as shown in Table 3 and is suitable for a wide variety of schemes (Boado-Penas et al., 2008; Billig and Menard, 2013; Ventura-Marco and Vidal-Meliá, 2014; Vidal-Meliá, 2014; Pérez-Salamero et al., 2017; Metzger, 2018; Vidal-Meliá et al., 2018; Metzger, 2019; Garvey et al., 2020).

For the sake of brevity, in Table 3 the contingencies covered by the system are shown as a whole, but the commitments deriving from non-contributory rights (NCRs) are specifically accounted for.

The right-hand side of the table shows the liabilities to contributors and pensioners and sponsor support (capital). The liability to pensioners can be defined in general terms as the present value of all the benefits in payment stemming from contributory rights plus noncontributory rights at the valuation date of the balance sheet. When referring to contributors, the specialized literature uses the term "technical provisions for rights being acquired", which will be reported here as liabilities to contributors.

Table 3: The ABS for an already-functioning scheme with a minimum pension benefit (MPB).

\begin{tabular}{|c|c|}
\hline Assets & Liabilities and sponsor support \\
\hline \multirow{2}{*}{ Financial assets: $B F_{t}^{S}$} & Financial liabilities: $F L_{t}^{S}$ \\
\cline { 2 - 2 } Contribution asset: $C A_{t}^{S}$ & Sponsor support: $S s_{t}^{S}$ \\
\cline { 2 - 2 } & Liability to contributors: $V_{t}^{\boldsymbol{c}}$ \\
\hline \multirow{2}{*}{ Public contribution asset: $P C A_{t}^{S}$} & Liability to pensioners: $V_{t}^{\boldsymbol{p}}$ \\
\cline { 2 - 2 } & Liability to contributors: ${ }^{N C R} V_{t}^{c}$ \\
\hline Accumulated deficit: $A d_{t}^{S}$ & Liability to pensioners: ${ }^{N C R} V_{t}^{p}$ \\
\hline Actuarial losses for the period: $L_{t}^{S}$ & Accumulated surplus: $A s_{t}^{S}$ \\
\hline Total assets: $T A_{t}^{S}$ & Actuarial profit (gains) for the period: $P_{t}^{S}$ \\
\hline \multicolumn{2}{|c}{ Source: Own } \\
\hline
\end{tabular}

In line with the classic Swedish ABS (TSPS, 2020) - which basically aims to compute the value of the commitments to contributors and pensioners taken on by the system, rather than calculate how much the system would have to pay a third party if it was decided to contract out or transfer those commitments ${ }^{5}$ - the interest rate for discounting liabilities to pensioners is taken to be the rate of overall economic growth (Settergren and Mikula, 2005; Gronchi and Nisticò, 2008). The discount rate is denoted as $G_{t}$.

The left-hand side (or assets side) of Table 3 shows the main entries that can appear in the ABS. The present value of the (future) contribution flow is expressed as the contribution asset, i.e. the maximum level of liabilities that would exist on the last day of the accounting period if there were no changes in the age-related income distribution, age-related mortality and disability, the size of the contribution ( $\operatorname{tax}$ ) base, the structure of the pensions or the pension system rules.

\footnotetext{
${ }^{5}$ How pension plans should account for the value of their liabilities is a prominent policy issue. Brown and Pennacchi (2016) argue that the appropriate rate for discounting depends on the purpose of the discounting exercise.
} 
The value of this contribution flow (i.e. the contribution asset, $C A_{t}^{S}$ ) is estimated by multiplying the system's current contribution revenue $\left(C_{t}^{S}\right)$ for the period for all the contributory contingencies included in the system by the time expected to elapse between the payment of the contributions and receipt of the pensions (turnover duration, $T D_{t}^{S}$ ). This could be interpreted as being equivalent to discounting an assumed perpetual constant flow of contributions by the inverse of the $T D$ (see Formula 1 in Appendix 1)

The $T D_{t}^{S}$ for the system is interpreted as being the number of years expected to elapse before the committed liabilities with contributors (pay-in, $p t_{c}^{S}$ ) and pensioners (pay-out, $p t_{p}^{S}$ ) are completely renewed at the current contribution level. It is calculated as the difference in the weighted average ages of the pensioners $\left(A_{p}^{S}\right)$ and contributors $\left(A_{c}^{S}\right)$, where the weighting is their economic amounts (i.e. affiliate contributions and pensioner benefits).

The system's turnover duration can be calculated as the weighted average of the $T D_{t}^{S}$ for all the pension system's covered contingencies (retirement, disability, survivor benefits), where the weighting is the spending on pensions by contingency as a proportion of total spending ${ }^{6}$.

To preserve solvency, the asset counterpart that underwrites the liabilities caused by NCRs can appear as a special type of public contribution asset, financed by general government revenues.

It is also straightforward to obtain the value of the system's public contribution asset $\left(C A_{t}^{S}\right)$. It is the product of the system's turnover duration $\left(T D_{t}^{S}\right)$ and the value of the $N C R$ public contributions $\left(S C_{t}^{S}\right)$ made in the period by the sponsor in order to pay for the MPBS.

The net worth is a balancing item that emerges from valuing assets and liabilities (including sponsor support if any) according to the accounting principles used on the date of the balance sheet. Net worth can be positive, negative or zero, and is equal to the accumulated surplus plus the profit or, where appropriate, minus the loss for the period. It can also be equal to the accumulated shortfall plus the actuarial losses or, where applicable, minus the profit for the period.

The system's solvency indicator is the ratio between its assets and liabilities $\left(S I_{t}^{S}\right)$ (see Formula 2 in Appendix 1). It is denoted as primary $\left(P S I_{t}^{S}\right)$ if the public contribution asset is excluded $\left(P C A_{t}^{S}\right)$.

At the valuation date the balance ratio value will be 1 if the net worth is zero or greater than 1 if it is positive.

Our proposal measures sustainability via the solvency indicator under a mature-state assumption with respect to the year of the valuation date. If the time interval between new estimates of the solvency indicator is short enough (a year), each interval between can be interpreted as a transitory steady state (Lee, 2006). This is the approach followed in practice by the Swedish authorities (TSPS, 2020), and therefore - on the practical side, at least - the mature state assumed by this accounting framework cannot be viewed as a limitation.

Another valuable indicator of the system's sustainability is the required growth rate $\left(G_{t}^{*}\right)$, which actuarially matches the pension system's liabilities with its assets at the valuation date. To put it another way, this is the expected discount rate necessary to achieve the system's

\footnotetext{
${ }^{6}$ For full technical details, interested readers can consult the papers by: Settergren and Mikula (2005) and Boado-Penas et al. (2008) for the retirement contingency; Ventura-Marco and Vidal-Meliá (2014)(2016), PérezSalamero et al. (2017) and Garvey et al. (2020) for disability and minimum pension benefits, and Vidal-Meliá et al. (2018) for long-term care and retirement.
} 
solvency $\left(S I_{t}^{S}=1\right)$ (see Formula 3 in Appendix 1) The required growth rate is denoted as primary $\left(G_{t}^{* *}\right)$ if the public contribution asset is excluded from the calculation.

The difference between $G_{t}$ and $G_{t}^{*}$ is called the annual gap in growth, whereas the difference between $G_{t}$ and $G_{t}^{* *}$ is the primary annual gap in growth.

The balance sheet records changes in the value of the assets and liabilities over the course of the accounting period and the aggregated amounts recorded in the various accumulation accounts. Indeed, this is the definition of the income statement (IS) (Eurostat, 2013), which quantifies changes in solvency by means of differences in the system's net worth.

It is clear that the ABS and the IS are closely linked (Table 4). In fact, the "net profit" for a period can be computed without an IS. The simplest way of determining the change in the system's net worth is by comparing the opening and closing entries on the ABS, but this would involve a significant lack of detail.

The IS ${ }^{7}$ presents the results of a company's (or in our context, a pension scheme's) operations for a given period. It provides a summary of an entity's revenues, gains, expenses, losses and net income or net loss for the period.

Table 4: The IS for an already-functioning scheme with an MPB

\begin{tabular}{|c|c|}
\hline Fund Assets (Changes): $\delta B F_{t}^{S}$ & Liabilities (Changes): $\delta V_{t}^{S}$ \\
\hline Value of change in financial loans: $\delta F L_{t}^{S}$ & Value of change in financial loans: $\delta F L_{t}^{S}$ \\
\hline Pension contributions: $C_{t}^{S}$ & New pension credit: $C_{t}^{S}$ \\
\hline Sponsor contributions for NCRs: ${ }^{N C R} S C_{t}^{S}$ & Recognition of NCRs: $R_{t}^{S}$ \\
\hline Pension disbursements: $-P T_{t}^{S}$ & Pension disbursements: $P T_{t}^{S}$ \\
\hline Net return on funded capital: $D_{t}^{S}$ & Indexation: $I_{t}^{S}$ \\
\hline Other outflows: $O o_{t}^{S}$ & Value of change in life expectancy: $\delta e_{t}^{S}$ \\
\hline $\begin{array}{c}\text { Contribution Asset (Changes): } \\
\delta C A_{t}^{S}\end{array}$ & $\begin{array}{c}\text { Value of change in other biometric } \\
\text { assumptions: } \delta B a_{t}^{S}\end{array}$ \\
\hline $\begin{array}{c}\text { Value of change in contribution revenue: } \\
\delta C_{t}^{T S}\end{array}$ & Value of change in discount rate: $\delta G_{t}^{S}$ \\
\hline $\begin{array}{c}\text { Value of change in turnover duration: } \\
\delta T D_{t}^{S}\end{array}$ & Net Gain/Loss \\
\hline \multicolumn{2}{|c|}{ Total Debit Side } \\
Source: Own based on Vidal et al., 2018, Garvey et al., 2020.
\end{tabular}

The proposed IS structure is shown in Table 4. The left-hand side shows the changes in assets, which are interpreted in the following way: a negative item (-) decreases the asset and a positive item $(+)$ increases it, by the amount shown. On the right-hand side we find the changes in pension liabilities, which need to be interpreted as follows: a negative item (-) decreases the pension liability and a positive item $(+)$ increases it, by the amount shown.

Beginning with the left-hand side, the annual change in the fund's assets (also known as the buffer fund) is the result of adding the income from all types of contributions to the return on funded capital, then deducting the pension disbursements and considering the value of changes in financial loans (the inflows due to new financial loans and the outflows caused by the amortization of other loans, if any). In this scheme there could be two types of contribution: (1) ordinary contributions, which are made by affiliates, and (2) extraordinary contributions, which are made by the sponsor to cover NCRs.

\footnotetext{
${ }^{7}$ Also called the profit and loss account.
} 
Pension contributions are used to pay beneficiaries. The surpluses or deficits that arise when pension contributions are greater or less than pension disbursements are absorbed by the buffer fund. Finally, the net return on funded capital includes dividends on assets held by public pension funds, with financial assets being valued at their market price on the last trading day of the year.

We also include an item called "other outflows". This is a balancing item to show the changes that occur in the disclosure of fund assets because it is impossible to balance the fund assets using the information available from SS institutions. This item needs to be introduced for pension systems when accounting practices are badly applied.

Also on the left-hand side we see the changes to the contribution asset broken down into contribution revenue and turnover duration. The value of the change in contribution revenue is the monetary value in terms of how much more (or less) liability can be financed by a higher (or lower) level of contributions compared to the preceding year.

The value of the change in the TD is a combined effect from a variety of causes. This amount synthesizes into a single number a great deal of information about the system's rules, the age distribution of the population, the age patterns of the labour supply and earnings, mortality (changes in life expectancy) and disability rates (changes in biometric assumptions) (PérezSalamero et al., 2017; Vidal et al., 2018; Garvey et al., 2020).

The first item we see on the right-hand side is the value of the change in financial loans. The system may have to resort to financial indebtedness in order to pay all the scheduled benefits. Treasury deficits can arise when pension contributions are less than pension disbursements in the period.

The second item is new pension credits. This accounting item should be identical to the income from contributions, but in practice both items may differ slightly for operational reasons.

The third item is the so-called "recognition of NCRs". Apart from certain demographic and economic circumstances, the annual amount for this item will depend on the criteria used to quantify the NCRs. Its balancing entry on the debit side is sponsor contributions for NCRs. Both amounts should match perfectly and correspond to the redistributive part of the scheme. This entry would include the effect of legislative reforms affecting minimum pension benefit levels.

The liability is reduced by the amount of pension expenses, given that pension payments are an amortization of the pension liability. The amount for pension disbursements should match on both sides of the IS.

Changes in pension liabilities due to benefits in payment and imputed contributions (the unwinding of the discount rate) are also accounted for.

The "value of change in life expectancy" entry, $\delta e_{t}^{S}$, is the annual update in life expectancy. This has increased notably over the past few decades and represents a key challenge for SS schemes. This item is in coherence with the accounting principle of updating main data on an annual basis.

The "value of change in other biometric assumptions" entry, $\delta B a_{t}^{S}$, includes the annual update of other assumptions, such as the disability incidence rate and changes in transition probabilities between disability states.

On the right-hand side we have also included an item known as the "value of change in the discount rate $(G)$ ", $\delta G_{t}^{S}$. The discount rate assumption is the most influential actuarial input affecting both solvency ratios and contribution requirements (Chen and Matkin, 2017). 
Generally speaking, the higher the discount rate used, the lower the reported present value of the liabilities and the stronger the pension plan's solvency position reported in the accounting statements.

Finally, a net income or loss for the year is accounted for on the right-hand side.

\section{4.-From "Table 29" to the actuarial balance sheet and the income statement}

\section{1.- The rationale behind our proposal: improving information for decision-making purposes.}

There is no doubt that the regulation introduced by the EU regarding the disclosure of an accrued-to-date liability (ADL) table by Member States is a step forward in terms of transparency and the provision of useful information for decision-making purposes. However, the information content needs to be progressively improved, since liabilities alone - while still of great importance - are insufficient without the corresponding assets to enable the system's sustainability and solvency to be evaluated. We therefore propose to construct an ABS (assets and liabilities) from the supplementary table, i.e. Table 29, to show its importance as a source of useful information.

Our proposal is similar to the one put forward by the International Public Sector Accounting Standards Board (IPSASB, 2020), which explains in its conceptual framework (CF) that the aim of financial reporting by public sector entities is to provide information about any particular entity for the purposes of accountability and decision-making. It also explains that financial reporting is not an end in itself but has the aim of providing useful information to the users of general-purpose financial reports (GPFRs). It is the information needs of their users, therefore, that condition the content of financial reports.

According to the CF (IPSASB, 2020), GPFRs should be prepared primarily bearing in mind the needs of primary users. Citizens are considered to be primary users. In the specific case of a pension system, citizens are both beneficiaries and major contributors. When referring to accountability and decision-making, the CF (IPSASB, 2020) clearly explains that governments and other public sector entities are accountable to those who provide them with resources and to those who depend on them to use those resources to deliver services not only during the reporting period, but over a much longer period of time. Information about the entity's management of the resources entrusted to it for the delivery of services to beneficiaries and others forms part of its compliance with the obligations of accountability. In meeting the obligation of informing users, the CF specifically mentions their needs as regards the entity's performance, its liquidity and solvency, the sustainability of its service delivery and other operations over the long term and its ability to adapt to changing circumstances.

The preface to the CF (IPSASB, 2020) refers to the nature of public sector programmes and the longevity of the public sector. It focuses on the fact that many public sector programmes are long term and that their capacity to meet future commitments depends on future contributions and taxation (an SS scheme would be a typical example). Commitments arising from public sector programmes and the powers to levy future taxation do not fall under the definition of assets and liabilities according to International Public Sector Accounting Standards (IPSASs). Therefore future commitments are not usually included in financial statements, especially when these are not prepared according to the accruals principle. This highlights the need to provide useful information for accountability and decision-making purposes.

Of extreme interest is the indication that the going concern principle underpins the preparation of financial statements, and any interpretation of this principle should take into 
account the system's sustainability. Indeed, IPSAS 1 entitled Presentation of Financial Statements specifically states that an entity should be assessed according to its ability to continue as a going concern. This standard also indicates that the going concern principle should be used unless there is an intention to liquidate or to cease operating or if there is no alternative but to conclude the activity. If those who prepare the information and those responsible for it are aware of any material uncertainties that may cast doubt on the entity's ability to continue as a going concern, then these uncertainties should be disclosed. Similarly, if the statements are not prepared on a going concern basis, this should also be disclosed along with the reasons for it.

The IPSASB outlines six qualitative characteristics of all financial and non-financial information reported in GPFRs relating to historical, prospective and explanatory information: relevance, faithful representation, understandability, timeliness, comparability and verifiability. Materiality and cost-benefit are included as two pervasive constraints that are used to achieve a suitable balance between the qualitative characteristics. Relevance and faithful representation are considered fundamental, while the others are seen as enhancing qualitative characteristics. Matters identified as fundamental are considered to be more important than those identified as enhancing. Nevertheless, both types of characteristic are important and when used together contribute to the usefulness of the information.

In the following paragraphs we focus on the first of the qualitative characteristics, which is relevance. According to the CF (IPSASB, 2020), information is relevant if it can make a difference in achieving the objectives of financial reporting. For information to be capable of making a difference, it needs to have confirmatory and predictive value. Confirmatory value is said to be achieved if the information confirms or changes past or present expectations. This includes confirmation of expectations that management will discharge their responsibilities for the efficient and effective use of resources and that delivery of specified service objectives and compliance with budgetary, legislative and other requirements will be achieved.

We would question whether the information disclosed in Table 29, for example, fully complies with the relevance characteristic, because in our opinion it is incomplete without details of the assets, especially as regards the system's solvency. The CF (IPSASB, 2020) explains that GPFRs may present information about an entity's future service delivery activities, objectives and cost, including the amount and sources of the resources that are to be allocated to providing services in the future. This information can have predictive value and be relevant for accountability and decision-making purposes. The CF also discusses the way confirmatory and predictive roles interrelate. Information on the structure and current level of an entity's resources and the claims to be made on them helps to confirm the outcome of resource management strategies during the period. This allows predictions to be made about how likely it is that the entity will be able to deliver services in the future, taking into account its response to changing circumstances.

According to the CF (IPSASB, 2020), materiality is one of two pervasive constraints used to obtain a suitable balance with the qualitative characteristics. Information is material if its omission or misstatement could influence the discharge of accountability by the entity or the decisions that users make on the basis of the entity's GPFRs prepared for that reporting period. The $\mathrm{CF}$ also states that materiality depends on both the nature and the amount of the item being judged in the specific circumstances of the entity. GPFRs may encompass not only quantitative and qualitative information about service delivery achievements during the reporting period, but also expectations for service delivery in the future. Because they include both quantitative and qualitative information, it is not possible to specify a uniform quantitative threshold at which information becomes material. Materiality therefore has to 
be taken into account by those who prepare GPFRs, and this calls for the use of professional judgement.

In line with improving information for the purposes of decision-making and accountability, the system's corresponding assets should be included alongside its liabilities. Reporting liabilities is essential but in itself is of limited use. However, including the assets helps a user to make informed decisions. The liabilities alone do not give information about the system's solvency. Showing the assets makes it clear how far the liabilities are backed up by corresponding assets and basically whether future obligations can be paid. If the system is insolvent, then users can demand that the sponsor should cover the deficit or adjust contributions to eliminate any deficit over a suitable period of time, for example, or request a change in the system's rules. The availability of more complete information can also influence appeals made to political parties and even how users may use their vote in the future.

Including the corresponding assets also gives information about the system's management of the resources entrusted to it and how successful the scheme's administrators have been as regards delivering promises and adapting to changes in circumstances. This would cover the objective of accountability by being transparent about the system's liquidity, solvency and sustainability and about whether or not the system is able to continue as a going concern. The income statement would then show in greater detail the breakdown of the change in net worth over the period, and the scheme's performance could then be more openly interpreted taking into account economic and demographic changes during the reporting period.

All of the above explains the reasons for our proposal to take structured steps from the information we have (Table 29) with the aim of constructing an estimated ABS to allow us to see the wood as well as the trees.

\section{2.- The proposal.}

A good way to synthesize our proposal is through a stock and flow model ${ }^{8}$ (Figure 1) with the following items. Stock at t-1: pension entitlements, other liabilities and the system's assets at the beginning of the period. Stock at t: pension entitlements, other liabilities and the system's assets at the end of the period along with transactions and other flows between $t-1$ and $t$. All transactions and other economic flows that lead to a change in the opening and the closing stock within the given period are included.

\footnotetext{
${ }^{8}$ Flows refers to the actions and effects of events that take place within a given period of time, while stocks refers to positions at a particular point of time. Stocks are the holdings of assets and liabilities at a particular point in time.
} 
Figure 1: The system's assets and liabilities on two consecutive valuation dates and their changes

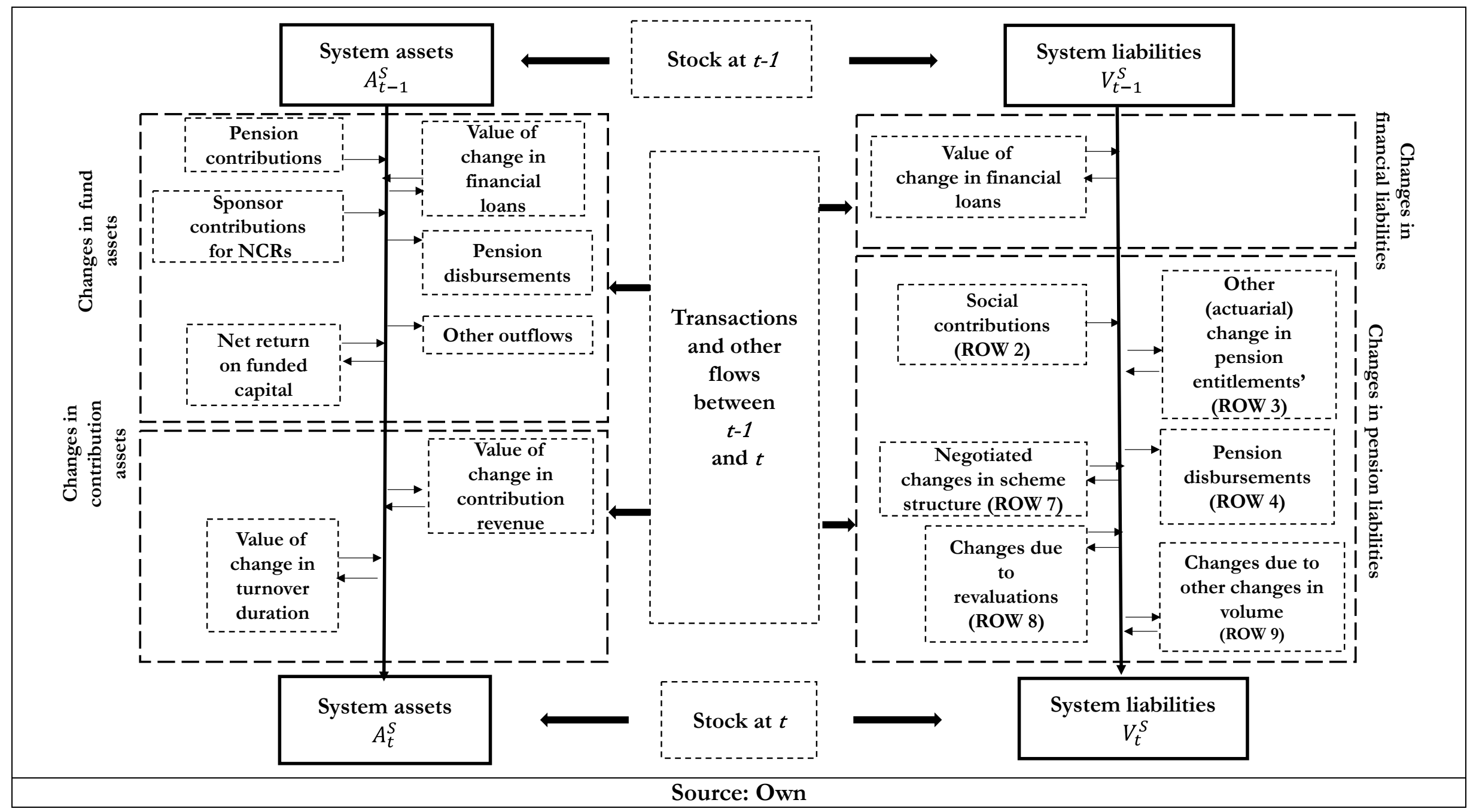


Figure 2: The system's changes in net worth: actuarial profits and losses for the period

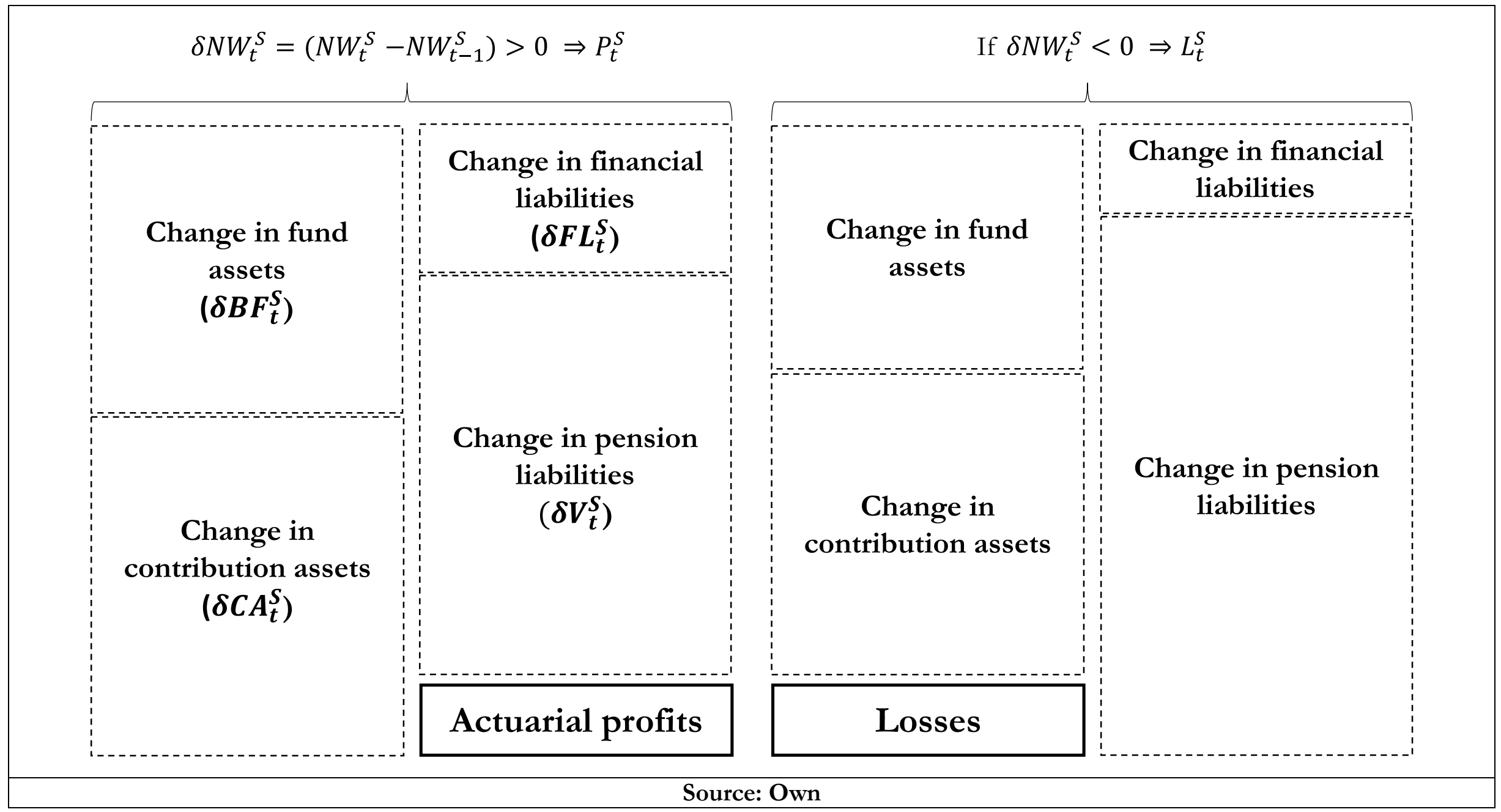


The system's assets and liabilities on two consecutive valuation dates along with their changes are shown in Figure 1. We can see the reconciliation between the opening stock of pension assets and liabilities at the beginning of a period and the closing stock of assets and pension obligations at the end of a period, taking into account all transactions and other flows during the period. When an inset in Figure 1 has 2 arrows to the central line, each pointing in a different direction, this means that the value may be positive or negative. An outflow is represented by an arrow pointing in the direction of the inset from the central line, while an inflow is the opposite, an arrow pointing from the inset in the direction of the central line.

From an analytical point of view, the change in net worth can be calculated according to Formula 4 in Appendix 1. As the formula shows, the simplest way of determining the change in net worth $\left(\delta N W_{t}^{S}\right)$ is to compare the system's assets and liabilities on two consecutive valuation dates (Figure 2). The size of the insets in Figure 2 is irrelevant; they are for illustration purposes alone.

If $\delta N W_{t}^{S}>0 \Rightarrow P_{t}^{S}$, the change in net worth is positive, i.e. the sum of the items on the left-hand side is greater in value than the sum of the items on the right. This means that the system has actuarial profits for the period

If $\delta N W_{t}^{S}<0 \Rightarrow L_{t}^{S}$, the sum of the items on the right-hand side is greater in value than the sum of the items on the left. This means that the net worth has decreased and the system has actuarial losses for the period.

If $\delta N W_{t}^{S}=0$, the system's net worth is unchanged.

As can be seen in Figure 1, the changes in net worth can be broken down into four main items: 1.- the change in the fund/financial asset (Formula 5 in Appendix 1), 2.- the change in the contribution asset (Formula 6 in Appendix 1), 3.- the change in pension liability (Formula 7 in Appendix 1), and 4.- the change in financial liabilities (Formula 8 in Appendix 1).

Given that the aim of this paper is to easily transform Table 29 into an ABS and compile its corresponding IS, we use the supplementary table's structure and main figures to determine the pension liability on two consecutive valuation dates and the associated changes.

\section{5.-A country case study: Spain}

To enable policymakers and other potential users to better understand how the model would function, this section presents a country case study based on data from the most recently published Table 29 for Spain. Our starting point is the information published on the Instituto Nacional de Estadística (INE) website regarding pension obligations for the years 2015 and 2018, as would be entered on Table 29.

Table 5 presents the information referring exclusively to the SS system for these two years. This represents the lion's share of the liability and amounts to around $90 \%$ of the total. This liability includes retirement pensions, widow's and orphan's pensions, benefits to family members and pensions for permanent disability. The Spanish SS system includes two major regimes: the General Regime for paid employees and the Special Regime for Self-Employed Workers ${ }^{14}$.

\footnotetext{
${ }^{14}$ Historically, there have also been numerous special regimes (for sea workers, miners, writers, bullfighters, etc.), but they have gradually been assimilated into the General Regime. Some still exist and have their own specific characteristics due to the nature of the work that defines them.
} 
The state's Special Civil Service System (Clases Pasivas) is excluded because there is not enough information to properly calculate its contribution asset. We also exclude other employment-linked systems, which are a residual part of the pension liability.

We have omitted those rows in which all cells had zero values.

The main sources used by the INE (2020) to obtain the necessary data to determine the SS system's pension obligations are the following:

1. Pensioner information, benefits received and number of contributors in the various SS schemes of the Directorate General of Social Security Planning of the Ministry of Inclusion, Social Security and Migration.

2. Projections on the evolution of the average amounts of pensions awarded to new pensioners in the SS system as prepared by the Ministry of Economic Affairs and Digital Transformation and included as part of the work done by the Ageing Working Group (AWG) ${ }^{15}$.

3. Mortality tables projected for Spain in the Eurostat Population Projections 20192100.

4. Mortality tables as estimated by the Ministry of Labour, Migrations and Social Security are used for the disability scheme and for disability beneficiaries reclassified as retirement pensioners at the normal age of retirement.

5. General Government Accounts from the Audit Office (IGAE), supervised by the Ministry of Finance.

6. Continuous Sample of Working Lives (CSWL) ${ }^{16}$ prepared by the Ministry of Inclusion, Social Security and Migration.

\footnotetext{
${ }^{15}$ The EU's Economic Policy Committee's Working Group on Ageing Populations and Sustainability (AWG) was set up to help improve the quantitative assessment of the long-term sustainability of public finances and the economic consequences of ageing populations for Member States in order to assist with policy formation. ${ }^{16}$ Muestra Continua de Vidas Laborales in Spanish, also referred to by several authors as the Continuous Working Life Sample (CWLS) or the Continuous Survey of Working Lives (CSWL). The CSWL contains administrative data on working lives that form the basis of this sample taken from Spanish social security records and comprises anonymized microdata with detailed information on individuals. It provides a unique data set with very rich information about employment histories and personal characteristics (Pérez-Salamero et al. 2017; Núñez-Antón, et al. 2020).
} 
Table 5: Pension table (base scenario). Years 2015 and 2018. Social Security. Spain. Unit: EUR million.

\begin{tabular}{|c|c|c|c|c|}
\hline Code & Row No. & Item & 2015 & 2018 \\
\hline F.63 & 1 & $\begin{array}{l}\text { Pension entitlements at } 31 \text { December } \\
2014 / 2017\end{array}$ & $2,661,993$ & $3,674,044$ \\
\hline D.61 & 2 & Increase due to social contributions & 227,846 & 254,272 \\
\hline D.6111 & 2.1 & Employers current social contributions & 67,592 & 78,306 \\
\hline D.6131 & 2.3 & Households current social contributions & 27,154 & 29,004 \\
\hline D.6141 & 2.4 & Household social contribution supplements & 133,100 & 146,962 \\
\hline D.619 & 3 & $\begin{array}{l}\text { Other (actuarial) changes in pension } \\
\text { entitlements in social security pension } \\
\text { schemes }\end{array}$ & 18,394 & 117,979 \\
\hline D.62 & 4 & Reductions due to pension benefit payments & $-116,006$ & $-129,098$ \\
\hline D.8 & $\begin{array}{c}5 \\
(2+3-4) \\
\end{array}$ & $\begin{array}{l}\text { Changes in pension entitlements due to } \\
\text { social contributions and pension benefits }\end{array}$ & 130,234 & 243,153 \\
\hline F.63 & 10 & $\begin{array}{l}\text { Pension entitlements at } 31 \text { December } \\
2015 / 2018\end{array}$ & $2,792,227$ & $3,917,197$ \\
\hline \multicolumn{3}{|c|}{ Accumulated pension entitlements (\% of GDP 2015/2018) } & $263 \%$ & $326 \%$ \\
\hline \multicolumn{5}{|c|}{ Source: Own based on INE (2020) and INE (2018) } \\
\hline
\end{tabular}

Along with the use of dynamic mortality tables, the main assumptions are a nominal discount rate of 5\% and 4\% for 2015 and 2018 respectively, an inflation rate of $2 \%$ for both years, and pensions in payment indexed at $0.25 \%$ throughout the projected period. This latter assumption is not in line with the real inflation rate. In this case the INE (or at least the AWG, which is where this hypothesis comes from) has applied a certain type of "managerial discretion" or "accounting choice". This is not unusual. Such inappropriate practices have been used in both the public (Naughton, et al., 2015) and private sectors (Billings et al., 2017).

According to the principle of verifiability of facts and transactions at the date the valuation is performed, the assumption made by the INE (AWG) is clearly biased ${ }^{17}$. Pensions in payment were increased by $1.6 \%$ in both 2018 and 2019, and these improvements were higher than the retail price index (RPI) in Spain for the same period. Indeed, pensions in payment were increased in real terms (i.e. above the RPI) in six of the years between 2009 and 2018.

An SS scheme should measure its defined benefit obligations on a basis that reflects its estimations regarding future changes in the benefits payable. Historical data or other reliable evidence are used to determine the future indexing rate. For example, it is normal to assume that pensions in payment will be updated in line with future changes in general price or general salary levels (IFRS, 2011) ${ }^{18}$.

It can be said that the assumption made by the AWG is overly conservative and has brought about an underestimation of pension liability. Therefore, due to the assumptions made, the liabilities reported in Table 5 should not be confused with the cost of transferring to a fully funded pension system the obligation to pay the commitments. The cost of fully funding the

\footnotetext{
${ }^{17}$ Best practice for DB schemes (funded and unfunded) in actuarial valuations considers that assumptions are unbiased if they are neither imprudent nor excessively conservative. Actuarial assumptions are mutually compatible if they reflect the economic relationships between factors such as inflation, increases in rates of salary and discount rates (IFRS, 2011).

${ }^{18}$ International Accounting Standard No. 19 (IAS 19) (McNally et al., 2019) provides internationally recognized guidance on accounting and disclosure requirements for the financial statements of defined benefit pension benefits and obligations.
} 
liabilities would actually be (much) more than that indicated by the official data from the INE.

Table 6 presents what is considered to be an extension of Table 29, which includes the system's income statement for 2018, and the resulting simplified ABS for the same period. Table 7 shows the main data and indicators emerging from Table 6. Tables A1 and A2 in the Appendix replicate Tables 6 and 7 for the period 2014-2015.

Table 6: The ABS and IS for 2018. Social Security scheme. Spain. Unit: EUR million.

\begin{tabular}{|c|c|c|c|}
\hline \multicolumn{4}{|c|}{ Income Statement for 2018} \\
\hline ASSETS 1-1-2018 & $3,214,347$ & $4,100,270$ & LIABILITIES 1-1-2018 \\
\hline Financial assets & 8,095 & 10,192 & Financial liabilities \\
\hline Contribution assets & $3,206,252$ & $4,090,078$ & Pension entitlements \\
\hline Change in fund assets & $-3,035$ & 13,830 & Change in financial liabilities \\
\hline $\begin{array}{l}\text { Value of change in financial } \\
\text { loans }\end{array}$ & 13,830 & 284,965 & Change in pension entitlements \\
\hline Pension contributions & 107,310 & 276,814 & Social contributions \\
\hline $\begin{array}{c}\text { Sponsor contributions for } \\
\text { NCRs }\end{array}$ & 18,082 & 78,306 & Employer contributions \\
\hline Pension disbursements & $-129,098$ & 29,004 & Household contributions \\
\hline Net return on funded capital & -53 & 169,504 & $\begin{array}{c}\text { Household social } \\
\text { contribution supplements }\end{array}$ \\
\hline Other outflows & $-13,106$ & 133,745 & $\begin{array}{l}\text { Other (actuarial) changes } \\
\text { in pension entitlements }\end{array}$ \\
\hline $\begin{array}{c}\text { Changes in } \\
\text { contribution assets }\end{array}$ & 201,206 & $-129,098$ & Payment of pension benefits \\
\hline $\begin{array}{c}\text { Value of change in } \\
\text { contribution revenue }\end{array}$ & 191,113 & 3,505 & $\begin{array}{c}\text { Changes in entitlements due to } \\
\text { revaluations and other }\end{array}$ \\
\hline Value of change in TD & 10,092 & 3,505 & $\begin{array}{c}\text { Changes in entitlements } \\
\text { due to revaluations }\end{array}$ \\
\hline $\begin{array}{l}\text { Total change } \\
\text { in system assets }\end{array}$ & 198,170 & 298,795 & $\begin{array}{c}\text { Total change } \\
\text { in system liabilities }\end{array}$ \\
\hline ACTUARIAL LOSSES & 100,625 & & \\
\hline \multicolumn{4}{|c|}{ Actuarial Balance Sheet at 31-12-2018 } \\
\hline ASSETS 31-12-2018 & $3,412,517$ & $4,399,065$ & LIABILITIES 31-12-2018 \\
\hline Financial assets & 5,060 & 24,022 & Financial liabilities \\
\hline Contribution assets & $3,407,457$ & $4,375,043$ & Pension entitlements \\
\hline $\begin{array}{l}\text { ACCUMULATED } \\
\text { SHORTFALL } \\
\end{array}$ & 885,923 & & \\
\hline ACTUARIAL LOSSES & 100,625 & & \\
\hline TOTAL DEBIT SIDE & $4,399,065$ & $4,399,065$ & TOTAL CREDIT SIDE \\
\hline
\end{tabular}

The pension liability side is estimated on the basis of official data. The pension liability needs to be recalculated, since the discount rate considered to be the best estimate is different (4.14\% and 4.15\% for 2018 and 2017 respectively) to the rate applied (4\%). Given that the result for the TD is around 27 years $^{19}$ (see Row 3 in Table 7 below, and Figure 3), in line with

\footnotetext{
${ }^{19}$ Own elaboration based on data obtained from Seguridad Social (2021).
} 
the principle of verifiable facts and transactions, the rate of average annual GDP growth for the 27 years immediately prior to the date the ABS was compiled is used as the discount rate.

As indicated in Section 3, the system's turnover duration is a relevant element for calculating the contribution asset. Its value for Spain (TDs_Sp) was very stable over the period represented. If only the retirement contingency (TDr_Sp) is considered, then the value would be between 1.5 and 2 years higher. Such a value is comparable to that provided by the Swedish system (TD_Sw) (TSPS, 2018 and 2020), which only includes the retirement contingency. It can be seen that the differences between the two countries tend to decrease ${ }^{20}$. Finally, the value of the TD for the disability contingency (TDr_Sp) is also shown. It is much lower than for the retirement contingency because, once disability beneficiaries reach the ordinary retirement age, these pensioners are reclassified as retirement pensioners.

The system's pension liabilities as shown in Table 6 and Table A1 (Appendix 2) are estimated in accordance with Formula 9 in Appendix 1.

The first thing that draws our attention is the significant amount of actuarial losses in the income statement for the 2018 financial year: 100,625 million euros. This is approximately $8.37 \%$ of GDP for 2018 (Row 7 in Table 7). It is worth recalling that the system's annual profit or loss is the difference between the increase in assets and the increase in liabilities during that period. The above figure is therefore a direct consequence of the system's increase in liabilities being much higher, 298,795 million euros, than the estimated increase in the system's assets, which was 198,170 million euros. The system's liabilities have increased both in its financial aspect, i.e. 13,830 million euros from new loans to meet the payment of the promised pensions, and in its liabilities to contributors and pensioners, for an amount of 284,965 million euros.

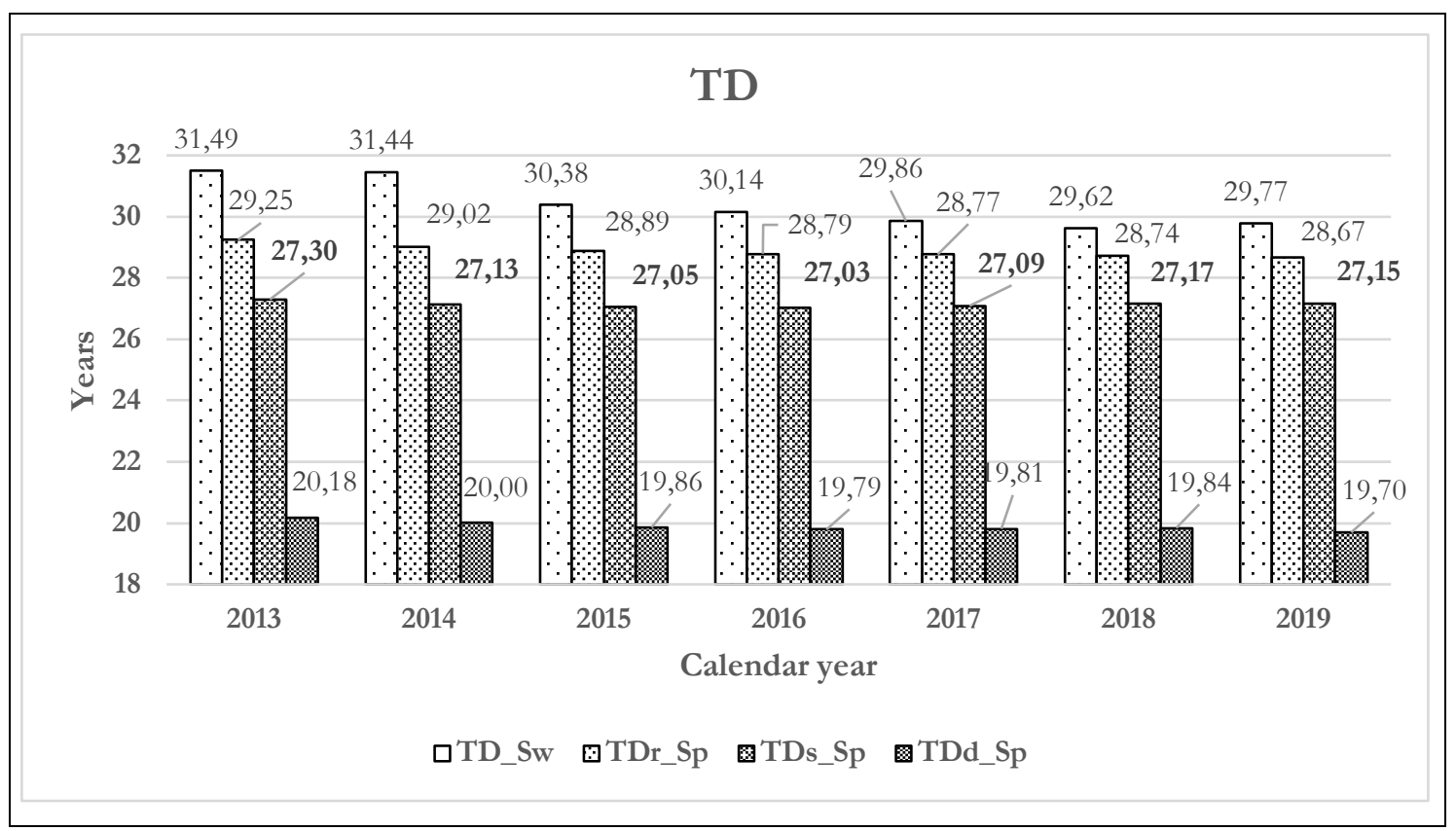

Figure 3: Evolution of the turnover duration in Spain and Sweden (2013-2019)

The item "other (actuarial) changes in pension entitlements", which amounts to 133,745 million euros, is also remarkable for being so big. As we explained in Section 2, this item can be positive or negative. In this case the extraordinarily high positive amount is mainly due to the fact that the scheme's discount rate is lower than its internal rate of return.

\footnotetext{
20 The explanation for this is complex and clearly goes beyond the scope of this paper.
} 
The increase in the system's assets during the period derives from contributions, including state contributions or income, the amount of which totals 201,206 million euros. This is determined by applying Formula 6 (data from $T D_{t}^{S}$ ) for each of the years shown in Column 3 of Table 7. Meanwhile the system's financial assets (the reserve fund) have decreased by 3,035 million euros. In reality, the reserve fund should have a zero value, since the system is getting into debt to pay the benefits. The real balance of the reserve fund at 31-12-2018 is 18.962 million euros, but for purely political reasons the fiction is maintained that the reserve fund - popularly known as "the pension piggy bank" - still exists.

The opening ABS at 1-1-2018 already showed a notable imbalance between the system's liabilities and assets, with a solvency ratio value of 0.7839 (Row 6 in Table 7 below). The ABS at 31-12-2018 includes the system's transactions during the year, i.e. the actuarial losses are incorporated. The consequence of this is that the solvency ratio worsens, reaching a value of 0.7757 . But what does this really mean? The fact is that $22.43 \%$ of the commitments taken on are uncovered, or to put it another way, only $77.57 \%$ of the actuarial liabilities are backed up by assets. This means that at some point in the future the sponsor will be forced to allocate extraordinary funds to cover the accumulated deficit, otherwise the promises made to at least some of the participants will be at least partially broken.

Table 7: ABS and IS indicators for 2017 and

2018

\begin{tabular}{|c|c|c|c|c|}
\hline $\begin{array}{l}\text { Row } \\
\text { No. }\end{array}$ & Items & Units & 2018 & 2017 \\
\hline 1 & $A_{p}^{S}$ & \multirow{3}{*}{ Years } & 71.61 & 71.45 \\
\hline 2 & $A_{C}^{S}$ & & 44.44 & 44.36 \\
\hline 3 & $T D_{t}^{S}$ & & 27.17 & 27.09 \\
\hline 4 & $\frac{C t_{t}^{S}}{P s_{t}}$ & Ratio & 2.15 & 2.11 \\
\hline 5 & $P S I_{t}^{S}$ & \multirow{2}{*}{$\begin{array}{c}\text { Between } \\
0 \text { and } 1\end{array}$} & 0.6640 & 0.6764 \\
\hline 6 & $S I_{t}^{S}$ & & 0.7757 & 0.7839 \\
\hline 7 & $\frac{L_{t}^{S}}{G D P_{t}}$ & \multirow{7}{*}{$\%$} & $8.37 \%$ & \\
\hline 8 & $\frac{A d_{t}^{S}+L_{t}^{S}}{G D P_{t}}$ & & $82.06 \%$ & $76.25 \%$ \\
\hline 9 & $\frac{V_{t}^{S}}{G D P_{t}}$ & & $363.92 \%$ & $352.02 \%$ \\
\hline 10 & $G_{t}^{*}$ & & $3.45 \%$ & $3.43 \%$ \\
\hline 11 & Gap in $G_{t}^{*}$ & & $1.35 \%$ & $1.32 \%$ \\
\hline 12 & $G_{t}^{* *}$ & & $4.14 \%$ & $4.10 \%$ \\
\hline 13 & Gap in $G_{t}^{* *}$ & & $2.03 \%$ & $2.00 \%$ \\
\hline
\end{tabular}

It is worth remembering that the solvency indicator includes the transfers made by the state to the system as part of the public contribution asset. However, if these are excluded from the calculations, then what we have is the primary solvency index $\left(P S I_{t}^{S}\right.$ ) (Row 5 in Table 7). This provides a more realistic picture of the system's sustainability, and its values for 2017 (0.6764) and 2018 (0.6640) show the severity of the problem.

The system's accumulated liabilities in relation to GDP (Row 9 in Tables 7 and A2) show only increases, from 3.32 times GDP in 2014 to 3.64 times GDP in 2018. 
Figure 4 summarizes the evolution of the assets, liabilities and accumulated deficit (in $\%$ of GDP for each year) over the period analysed. The Spanish pension system is suffering a yearon-year increase in the accumulated deficit (degree of insolvency). For the period under analysis the liabilities grew at a higher annual cumulative rate $(6.47 \%)$ than the assets $(2.41 \%)$. Achieving solvency would only be possible if the liabilities grew at a much lower rate than the assets, which is precisely the opposite of what has been happening over the last few years.

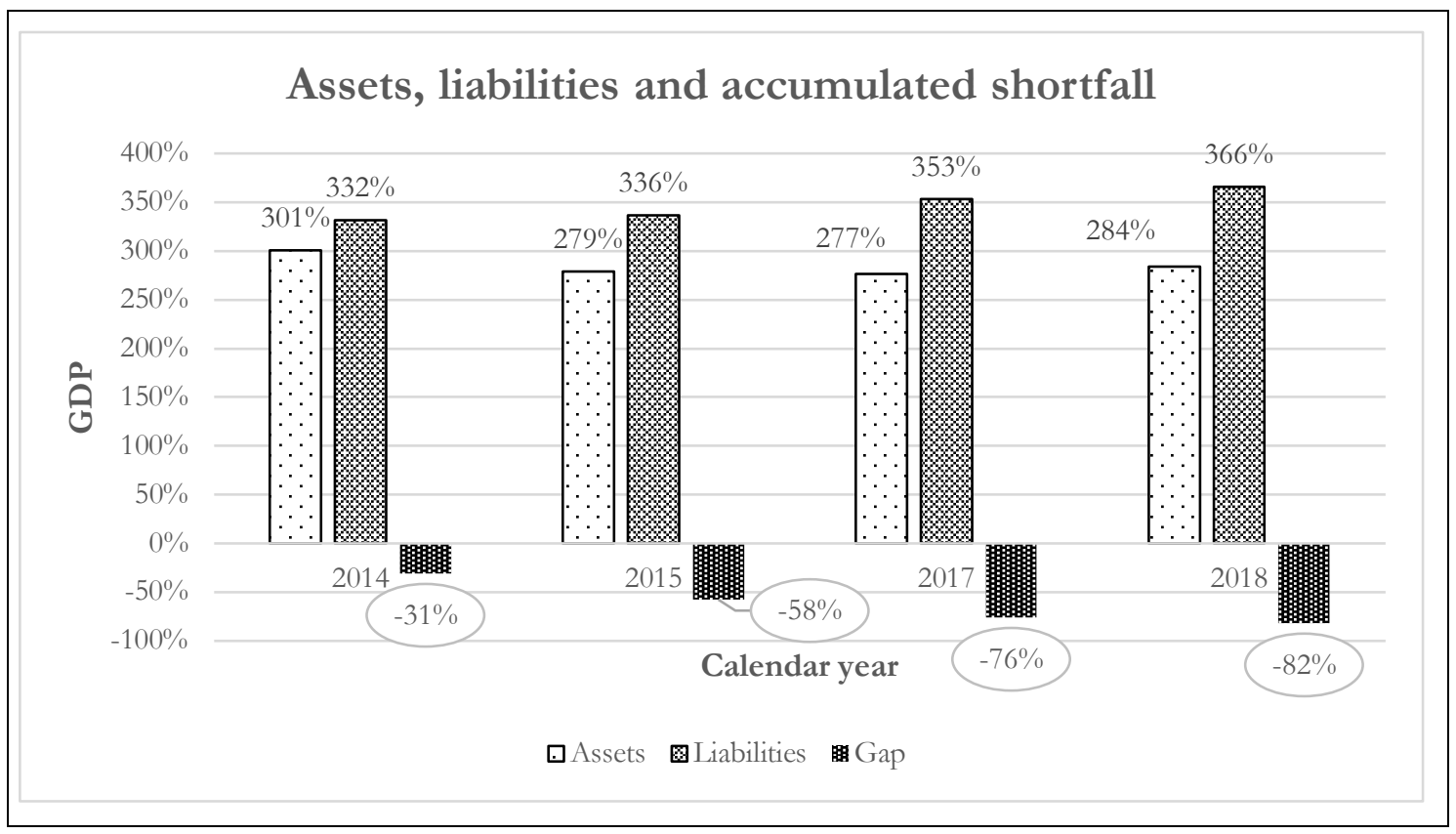

Figure 4: Evolution of the total assets, liabilities and accumulated shortfall (gap). Period 2014-2018.

How could the system's solvency be restored as of 31-12-2018? Table 7 shows two possible actions that could be taken and a future event that could raise the solvency ratio from its current value to 1 . Naturally, a combination of these three things would have a similar effect.

The first action stems from the solvency indicators for 2018. Given that the liabilities in that year exceed the assets by between $33.60 \%$ and $22.43 \%$ (Rows 5 and 6 in Table 7), pensioners and contributors could see the amounts they expected to receive reduced by the same proportion as the value of the acknowledged liability. In other words, the benefits provided to contributors and pensioners would be paid in a proportion of between $66.40 \%$ and $77.47 \%$. This is what would happen in a situation of insolvency through bankruptcy, where the amount of the liability is reduced to match the value of the assets.

Would this measure be politically viable? It seems unlikely, given that it was impossible to maintain even the pseudo-automatic adjustment mechanisms approved in the 2011-2013 reforms in Spain (Vidal-Meliá, 2014). Pensions in payment were traditionally indexed using the RPI until 2013, but a new index was introduced in 2014: the new pension revaluation index (IRP in Spanish). This was suspended in 2018. Pensions in payment were increased by $1.6 \%$ in both 2018 and 2019 in line with the RPI, whereas they would only have increased by $0.25 \%$ had the IRP formula been applied. The sustainability factor, which was supposed to apply from January 2019 to adjust initial pensions to account for changes in life expectancy, was also suspended until 2023. A committee will determine how to proceed with both the new indexation mechanism and the sustainability factor beyond 2023 .

To summarize, as long as the sponsor (the State) can continue to borrow, this first action seems to be completely ruled out. However, given the seriousness of the situation with public finances in Spain, we should not lose sight of the experience of Greece, where the accumulation of pension reductions since 2010 has led to a medium-term decrease in 
pensions of $40 \%$ - approximately $20-25 \%$ for low-income pensioners and up to $50 \%$ for higher pensions (Nektarios et al., 2018).

The second action would be for the promoter to make an extraordinary contribution amounting to $82.06 \%$ of GDP for that year (Row 8 Table 7 ). All losses would thus be eliminated from the system and the solvency ratio would have a value of 1 . Although this seems an extraordinarily high figure (and indeed it is, given that Spain has high levels of debt and public deficit), it is less than what would have to be contributed to restore sustainability to the US OASDI ${ }^{21}$ system - 65.9\% (BOT, 2019) - which has a lower contribution rate than Spain's $(12.40 \%$ compared to $28.30 \%)$ and a much higher contributor-to-pensioner ratio $(2.8$ compared to 2.15 (Row 4 Table 7))

The future event is that a miracle occurs in the form of economic growth. The real discount rate used to calculate pension liabilities in 2018 was $2.10 \%$, which corresponds to the annual real average growth of GDP for the last 27 years (1992-2018). Indeed, this implies that such a thing is to be expected to be true in the future. However, according to Moraga and Ramos (2020) the structural factors of the Spanish economy (e.g. population ageing and low productivity) point to only moderate potential growth in the future, no more than $1.3 \%$ in the short term.

The 2017 pension liabilities (which appear in Table 6 as liabilities at 1-1-2018) were calculated applying a rate of $2.11 \%$, the average annual real GDP growth rate for the period 1991-2017. As regards liabilities for pensions in 2015 and 2014, the discount rates applied were 2.20\% and $2.25 \%$ respectively. This is consistent with the principle of verifiable facts at the date of the valuation, while at the same time avoiding excessive volatility in the solvency indicator. In view of the values used, which slowly but inexorably reflect the decreasing growth rate of the Spanish economy, the question is what value should be used in order for the solvency index to be 1 .

The answer can be found in Rows 10 and 11 of Table 7. The discount rate (the future growth rate, ceteribus paribus) that should be applied is $1.35 \%$ higher in real terms than the rate recorded over the last 27 years. And if we wanted to eliminate any contribution from the sponsor in the form of transfers to the system (Rows 12 and 13 in Table 7), the estimated growth gap would have to be $2.03 \%$. In other words, the Spanish economy would need to grow cumulatively in real terms by $4.14 \%$ every year. It really would be a miracle, at least with current expectations, if the Spanish economy were to grow steadily at a rate of at least $65 \%$ higher than the average recorded in recent years

One thing we see that seems counterintuitive is that the solvency index worsens despite the fact that the ratio of contributors to pensioners improves over the period (Row 4 in Tables 7 and A2). This goes against the widely held belief that when this ratio improves, the system's financial health improves due to the increase in its income and liquidity.

This would be true if the system were actuarially balanced, i.e. if there were an equilibrium between the contributions that an individual is expected to make over the course of their working life and the benefits they will receive. The Spanish system suffers from a structural actuarial imbalance insofar as the relation between expected contributions and expected benefits "yields" too high an implicit internal rate of return (IRR) for the contributor. This is a problem that has been described and highlighted in the economic literature for some

\footnotetext{
21 The federal Old-Age, Survivors, and Disability Insurance (OASDI) programme is the official name for Social Security in the United States. The OASDI tax deducted from people's paychecks funds this comprehensive federal benefits programme, which provides benefits to retirees and disabled people along with their spouses, children and survivors.
} 
time now ${ }^{22}$. The reforms carried out during the period 2011-2013, which are not yet fully in force, have not served to restore this balance. Indeed, a recent study by the Bank of Spain (Moraga and Ramos, 2020) brought this problem back under the spotlight because, according to their estimations, the average IRR provided by the Spanish pension system for a sample of new retirees in 2017 was $3.5 \%$.

What measures would need to be applied if the public system were a DB pension plan covered by Spanish or OECD legislation? Vidal-Meliá et al. (2009) argue that this accumulated shortfall situation would require the immediate application of a recovery plan ${ }^{23}$. Under current Spanish legislation ${ }^{24}$, like in all other OECD countries (Yermo and Severinson, 2010), any pension plan deficit should be eliminated by extraordinary contributions from the sponsor (which in the public system is the State) within a period no greater than 5 years (or 10 years in exceptional cases).

Similar regulations can be found in OECD countries such as Canada, the Netherlands and the UK. In the case of Canada (Davis, 2011), the plan sponsor must make additional periodic contributions known as special payments to eliminate these shortfalls over a prescribed period of time (5 to 15 years). In the Netherlands (Franzen, 2010, 2013), pension funds are given a recovery period of three years to restore financial stability if the funding ratio falls below $105 \%$. This three-year deadline was temporarily extended to five years in the wake of the credit crunch crisis. In the case of UK DB pension schemes (Deloitte, 2017), when the statutory funding objective is not met and this results in a deficit in the pension fund, the employer and pension scheme trustee have to agree a recovery plan setting out the steps to be taken to put things right. Historically, the pension regulator has advised that deficits should be eliminated "as quickly as the employer can reasonably afford to". However, in July 2014 the pension regulator's new objective came into force, this being "to minimise any adverse impact on the sustainable growth of an employer".

In Spain it is also laid down by law that, when the accumulated deficit is greater than $10 \%$ (in the public system it is $22.43 \%$, as we have just seen), a review should be carried out of the assumptions that form the technical basis (equivalent to the parameters that determine payments in the public system) unless there are reasons to believe that the deficit has arisen for extraordinary reasons. Finally, the hypotheses used should be changed when the pension plan deficit, although below $10 \%$, still constitutes a substantial percentage and is present over the course of various tax years. Over the period analysed in this study the public system has shown losses and, in some cases, very high losses.

Table 8: Sensitivity analysis for the primary solvency indicator at the end of 2018

\begin{tabular}{|c|c|c|c|c|}
\hline $\boldsymbol{G} \% \downarrow ; \boldsymbol{\lambda} \% \rightarrow$ & $\mathbf{0 . 2 5}$ & $\mathbf{0 . 5}$ & $\mathbf{1}$ & $\mathbf{2}$ \\
\hline $\mathbf{4}$ & 0.8659 & 0.8265 & 0.7577 & 0.6494 \\
\hline $\mathbf{4 . 1 4}$ & 0.8895 & 0.8480 & 0.7757 & 0.6628 \\
\hline $\mathbf{4 . 5}$ & 0.9529 & 0.9057 & 0.8240 & 0.6981 \\
\hline $\mathbf{4 . 7 5}$ & 1.0029 & 0.9509 & 0.8614 & 0.7251 \\
\hline $\mathbf{5}$ & 1.0268 & 1.0006 & 0.9023 & 0.7541 \\
\hline \multicolumn{4}{|c|}{ Source: Own elaboration } \\
\hline
\end{tabular}

\footnotetext{
22 See the papers by Devesa-Carpio et al. (2002), Devesa-Carpio \& Vidal-Meliá (2004), Vidal-Meliá \& Domínguez-Fabián (2006), Vidal-Meliá et al. (2006), Boado-Penas et al. (2007) and Boado-Penas et al. (2008), to name just a few.

${ }^{23}$ The recovery plan must aim to eliminate the deficit so that the scheme meets the statutory funding objective (minimum solvency index).

${ }^{24}$ ORDER EHA/407/2008 of 7 February, which covers regulations governing the financial and actuarial aspects of pension plans and funds. (updated in 2014). https://www.boe.es/eli/es/o/2008/02/07/eha407
} 
Given that the solvency indicator critically depends on the assumptions made, to conclude this section Table 8 analyses what would happen to the primary solvency indicator at the end of 2018 if there were a change in both the relative value of pensions in payment $(\lambda \%)$ and the discount rate used $(G \%)$. The shaded cell shows the value for our best estimate assumption.

It can immediately be seen that the solvency indicator values that exceed one unit correspond to combinations of assumptions that are unrealistic for all the reasons we have considered in this section. It might even be said that our best estimate assumption is fairly conservative, since it would be closer to reality if we considered the change in the relative value of pensions in payment to be in line with expected inflation (dark shadowed cell).

\section{6.-Summary, concluding comments and future research.}

This paper is in line with the ongoing debate on how to recognize and measure the assets and liabilities of SS schemes. It has been said that the national accounts/statistical community should continue to develop additional guidelines and practices in order to record more consistent and internationally comparable statistics on SS schemes and other governmentsponsored pension schemes.

The regulation introduced by the EU regarding the disclosure of an accrued-to-date liability table (Table 29) is a valuable first step in reporting pension liabilities, although its actual usefulness for policymakers and stakeholders is in doubt.

The information disclosed in Table 29 is incomplete, since the breakdown of liabilities between contributors and pensioners is not presented. The division of the liability relating to the different contingencies that are covered - retirement, permanent disability and other contingencies - is not reported. The separation of liabilities deriving from contributory and non-contributory rights is also missing. And last but not least, because Table 29 does not provide an indicator of solvency or sustainability, pensioners and especially contributors have no information regarding the likelihood that they will receive their future benefits.

Our proposal relies on the SOG approach, which has two relevant positive features. Firstly, the way of measuring the system's assets and liabilities has a high degree of transparency and needs no complicated projections of economic, financial or demographic variables that could easily have a bias effect on the sustainability and solvency indicators. And secondly, this approach is suitable for the introduction of automatic balance mechanisms, given that the possibly endless debates as to the accuracy of long-term projections are avoided.

The rationale behind our proposal is twofold. In line with improving information for the purposes of decision-making and accountability, the system's assets should be included alongside its corresponding liabilities. Reporting liabilities is essential but in itself is of limited use. However, by including the assets a user can make informed decisions. The liabilities alone do not provide information as to the system's solvency. Including the assets would show the extent to which the liabilities are backed up by the corresponding assets and basically whether future obligations can be paid. If the system is insolvent, then users can make demands on the sponsor to cover the deficit or adjust contributions to eliminate any deficit over a suitable period of time. Or they could request a change in the system's rules. In addition, including an income statement would then show in greater detail the breakdown of the change in net worth over the period, which would mean that its performance could be more openly interpreted taking into account any economic and demographic changes during the reporting period

The extended Table 29 brings the model closer to the reality of social insurance and enhances its usefulness for stakeholders. 
Applying the model would enable policymakers to better understand how the system functions. The paper has developed a country case study based on data from the most recently published Table 29 for Spain. It confirms that our proposal works reasonably well because the results make sense and provide us with some useful insights regarding the financial health of the Spanish pension system. It also sheds light on the real applicability of the proposal. Judging by our best estimate assumptions, it can be said that the Spanish pension system is partially insolvent because only part of the pension entitlements is backed up by assets, and that the system's sustainability has markedly worsened over the period 2015-2018.

To be specific, the solvency indicator shows a value of 0.7757 at the end of 2018 . What this really means is that $22.43 \%$ of the system's commitments are uncovered, or that only $77.57 \%$ of the actuarial liabilities are backed up by assets. This means that at some point in the future the sponsor will be forced to allocate extraordinary funds to cover the accumulated deficit, otherwise the promises made to at least some of the participants will be at least partially broken. The Spanish system suffers from a structural actuarial imbalance insofar as the relation between the expected contributions and expected benefits "yields" too high an IRR for the contributor. The reforms made to the system during the period 2011-2013, which are not yet fully in force, have not served to restore this balance. The accumulated shortfall situation $-82.06 \%$ of GDP at the end of 2018 - would require the immediate application of a recovery plan.

The country case we have set out makes it even clearer that our proposal has practical implications that could be of interest to policymakers, statisticians, social security actuaries and public finance economists, given that the "extended Table 29" provides very useful information.

Regarding the question asked in the title of the paper, and bearing all the above reasons in mind, it can be said that transforming Table 29 into an ABS and compiling its associated IS is not as big a leap as one might initially think. And it is worth it because the improved usefulness of the information fully justifies it.

Finally, based on the proposal developed in the paper, at least one direction for future research can be identified regarding its application. All those countries that disclose Table 29 are, at least in theory, candidates for presenting the "extended Table 29" and gaining more detailed knowledge of their pension system's solvency. It would be interesting to perform the same exercise using the best estimate assumptions for each country. The main aim of this would be to compute the real level of accumulated shortfall (surplus) and to give reliable information to contributors and pensioners as to the likelihood that they will receive their future benefits.

\section{7.-References.}

Barr, N.; Diamond, P. (2009). Pension Reform: A Short Guide. Oxford University Press: New York, U.S.A.; ISBN13: 9780195387728.

Billig, A., and Ménard, J.C. (2013). Actuarial balance sheets as a tool to assess the sustainability of social security pension systems. International Social Security Review, 66(2), 3162.

Billings, M., O’Brien, C., Woods, M. and Vencappa, D. (2017). Discretion in accounting for pensions under IAS 19: using the 'magic telescope'? Accounting and Business Research, 47:2, 123 143, DOI: $10.1080 / 00014788.2016 .1205967$ 
Blanchet, D., Le Minez, S. and Marino, A. (2017). Building and interpreting macro/micro estimates of accrued-to-date pension liabilities: French reforms as a case study. Review of Income and Wealth 63(1), 70-94. DOI: 10.1111/roiw.12207

Boado-Penas, C. and Vidal-Meliá, C. (2013), "The Actuarial Balance of the Pay-As-You-Go Pension System: the Swedish NDC model versus the US DB model." In Holzmann, R., E. Palmer and D. Robalino, eds., NDC Pension Schemes in a Changing Pension World, Chapter 14, Volume 2. Washington, DC: World Bank.

Boado-Penas, M. C, Domínguez-Fabián, I. and Vidal-Meliá, C. (2007). Notional Defined Contribution Accounts (Ndcs): Solvency and Risk; Application to the Case of Spain International Social Security Review. 60 (4), 105-127.

Boado-Penas, M.C., Valdés-Prieto, S., and Vidal-Meliá, C. (2008). An Actuarial Balance Sheet for Pay-As-You-Go Finance: Solvency Indicators for Spain and Sweden. Fiscal Studies, 29(1), 89-134.

Board of Trustees, Federal Old-Age and Survivors Insurance and Disability Insurance Trust Funds (BOT). (2019). 2019 Annual Report. Washington, D.C.: Government Printing

Brown, J. and Pennacchi, G. (2016). Discounting pension liabilities: Funding versus value. Journal of Pension Economics and Finance, 15(3): 254-284.

Brys, I. (2017). Accrued-to-date pension entitlement in Belgium. Federal Planning Bureau. Economic Analyses and forecast Working Paper 6-17 (May 2017).

Chen, G. and Matkin, D.S. (2017). Actuarial inputs and the valuation of public pension liabilities and contribution requeriments: a simulation approach. Public Budgeting and finance, 37(1), 68-87.

Davis, R.B. (2011). Is Your Defined-Benefit Pension Guaranteed? Funding Rules, Insolvency Law and Pension Insurance. IRPP Study 16. Montreal: Institute for Research on Public Policy.

Deloitte (2017). Pension scheme valuations. Corporate guide. $2^{\text {nd }}$ edition https://www2.deloitte.com/content/dam/Deloitte/uk/Documents/consultancy/deloitteuk-pension-scheme-valuations-corp-guide.pdf

Devesa-Carpio, J. E., Lejárraga-García, A. and Vidal-Meliá, C. (2002). El tanto de rendimiento del sistema de pensiones de reparto. Revista de Economía Aplicada, 30 (X), 109132.

Devesa-Carpio, J.E. and Vidal-Meliá, C. (2004). Notional Defined Contributions Accounts (ndc's). What effect would they have had on the Spanish pension system? Moneda y Crédito, 219, 61-103.

Drouin, A., Plamondon, P. and Lloret, C. (2018). Towards a fair assessment of social security liabilities under pay-as-you-go and partially funded schemes. International Social Security Review, 71(3): 81-103.

EC et al. (2009). System of national accounts 2008. Brussels, European Commission, International Monetary Fund, Organisation for Economic Co-operation and Development, United Nations, World Bank.

Eurostat (2013). European system of accounts ESA 2010. Luxembourg.

Eurostat. (2020). Technical compilation guide for pension data in national accounts. Eurostat. 2020 edition. ISBN 978-92-76-21570-7. 
Franzen, D. (2010). "Managing Investment Risk in Defined Benefit Pension Funds", OECD Working Papers on Insurance and Private Pensions, No. 38, OECD.

Franzen, D. (2013). "The Impact of Regulation on the Asset Investment of Defined Benefit Pension Fund", Doctoral Thesis. School of Geography and the Environment. University of Oxford and St. Peter's College.

Garvey, A., Ventura-Marco, M. and Vidal-Meliá, C. (2020). Does the pension system's income statement really matter? A proposal for an NDC scheme with disability and minimum pension benefits. Economic Research-Ekonomska Istrą̌ivanja, DOI: 10.1080/1331677X.2020.1782246.

Goebel, P. (2017). "A Primer on Government-Sponsored Pension Schemes in the National Accounts and their Impact on the Interpretation of Government Debt Statistics", OECD Statistics Working Papers, No. 2017/05, OECD Publishing, Paris, https://doi.org/10.1787/c71c7727-en.

Gronchi, S.; Nisticò, S. (2008). Theoretical Foundations of Pay-as-You-Go DefinedContribution Pension Schemes. Metroeconomica, 59(2), 131-159.

Holzmann, R., Palacios, R. and Zviniene, A. (2001). On the economics and scope of implicit pension debt: an international perspective. Empirica, 28(1): 97-129.

Instituto Nacional de Estadística (INE) 2020. Pension Table. Inventory of Methods and Sources. https://www.ine.es/en/daco/daco42/cne10/inv fuentesymetodos TP en.pdf

International Financial Reporting Standard (IFRS) (2011). International Accounting Standard 19 (IAS19) Employee Benefits. ISBN: 978-1-907877-30-8. London. UK:

International Public Sector Accounting Standards Board. (IPSASB, 2020). IPSAS: The Conceptual Framework for Generally Purpose Financial by Public Sector Entities. In Handbook of international public sector accounting pronouncements 2020: Vol. 1. New York, NY: International Federation of Accountants - International Public Sector Accounting Standards Board.

Kaier, K. and Müller, C. (2015). New figures on unfunded public pensions entitlements across Europe: Concept, results and applications. Empirica, 42(4): 865-895

Lee, R. (2006). Discussion of "The Rate of Return of Pay-As-You-Go Pension Systems: A More Exact Consumption-Loan Model of Interest". In Pension Reform: Issues and Prospects for Notional Defined Contribution (NDC) Schemes, Holzmann, R., Palmer, E., Eds.; World Bank: Washington, DC, 2006; eISBN-10: 0-8213-6038-X. DOI: 10.1596/9780-8213-6038-5.

McNally, B., Garvey, A.M. and O'Connor, T. (2019). Valuation of defined benefit pension schemes in IAS 19 employee benefits - true and fair? Journal of Financial Regulation and Compliance, 27 (1), 31-42. https://doi.org/10.1108/JFRC-03-2018-0048

Metzger, C. (2018). An actuarial balance sheet of the Swiss old-age pension scheme. International Social Security Review, 71(1), 25-49.

Metzger, C. (2019). The German statutory pension scheme: Balance Sheet, Cross-sectional Internal Rates of Return and Implicit Tax Rates. Fiscal Studies: 40(2): 239-270.

Moraga, M. and Ramos, R. (2020). An estimate of pension system financial returns. Analytical articles. Economic Bulletin. 3-2020. Bank of Spain.

Müller, C. and Raffelhüschen, B. (2014). Estimating pension entitlements of public pension schemes in Latvia. Research Center for Generational Contracts, Freiburg University (April 2014). 
Naughton, J., Petacchi, R., and Weber, J., (2015). Public pension accounting rules and economic outcomes. Journal of Accounting and Economics, 59 (23), 221-241

Nektarios, M., Tinios, P., Simeonidis, G., (2018). Pensions for young people. A developmental system of social insurance, Athens: Papazisi.

Núñez-Antón, V., Pérez-Salamero González, J.M., Regúlez-Castillo, M., and Vidal-Meliá, C., (2020). Improving the Representativeness of a Simple Random Sample: An Optimization Model and Its Application to the Continuous Sample of Working Lives. Mathematics, 8 (8), 1225.

Office for National Statistics [ONS] (2018). Pension in the national accounts, a fuller picture of the UK's funded and unfunded pension obligations. 7 march 2018. https://www.ons.gov.uk/economy/nationalaccounts/uksectoraccounts/articles/pensionsi nthenationalaccountsafullerpictureoftheuksfundedandunfundedpensionobligations/2010to $\underline{2015}$

Pérez-Salamero González, J.M., Regúlez-Castillo, M. and Vidal-Meliá, C. (2017). The continuous sample of working lives: improving its representativeness. SERIEs. Journal of the Spanish Economic Association 8, 43-95.

Pérez-Salamero González, J.M., Ventura-Marco, M., and Vidal-Meliá, C. (2017). A 'Swedish' Actuarial Balance Sheet for a Notional Defined Contribution Pension Scheme with Disability and Minimum Pension Benefits. International Social Security Review, 70(3), 79-104.

Schmitz, C., Barb, F. and Bruil, A. (2015). Constructing the Supplementary Pension Table for the Netherlands. Statistics Netherlands Discussion Paper 2015/07.

Seguridad Social (2021). Muestra Continua de Vidas Laborales. Seguridad Social Estadísticas, Presupuestos y Estudios - Estadísticas. : http://www.segsocial.es/wps/portal/wss/internet/EstadisticasPresupuestosEstudios/Estadisticas/EST21. Accessed 21 February 2021.

Settergren, O. and Mikula, B.D. (2005). The rate of return of pay-as-you-go pension systems: a more exact consumption-loan model of interest. Journal of Pensions Economics and Finance, 4(2), 115-138.

Stavrakis, C. (2018). Reporting the pension obligations of social security schemes: An EU perspective. International Social Security Review. 71(3), 105-123.

The Swedish Pension System. (TSPS) (2002). Orange Annual Report 2001. Ed. Ole Settergren. The National Social Insurance Board (Riksförsäkringsverket, RFV), Stockholm. Sweden.

The Swedish Pension System. (TSPS) (2018). Orange Annual Report 2017. Ed. Ole Settergren. Swedish Pensions Agency (Pensionsmyndigheten), Stockholm. Sweden.

The Swedish Pension System. (TSPS, 2020). Orange Annual Report 2019. Ole Settergren (Ed.). Stockholm: Swedish Pensions Agency (Pensionsmyndigheten). Stockholm, Sweden.

Ventura-Marco, M., and Vidal-Meliá, C. (2014). An Actuarial Balance Sheet Model for Defined Benefit Pay-As-You-Go Pension Systems with Disability and Retirement Contingencies. Astin Bulletin, 44(2), 367-415.

Ventura-Marco, M., and Vidal-Meliá, C. (2016). Integrating retirement and permanent disability in NDC pension schemes. Applied Economics, 48(12), 1081-1102.

Vidal-Meliá, C. (2014). An assessment of the 2011 Spanish pension reform using the Swedish system as a benchmark. Journal of Pension Economics and Finance, 13(3), 297-333. 
Vidal-Meliá, C. and Domínguez-Fabián, I. (2006). "The Spanish Pension System: Issues of Introducing Notional Defined Contribution Accounts" In Pension Reform: Issues and Prospects for Notional Defined Contribution (NDC) Schemes, ed. R. Holzmann and E. Palmer, chapter 23. Washington, DC: World Bank.

Vidal-Meliá, C., Boado-Penas, M.C. and Settergren, O. (2009). Automatic Balance Mechanisms in Pay-As-You-Go Pension Systems. The Geneva Papers on Risk and Insurance: Issues and Practice. 33 (4), 287-317.

Vidal-Meliá, C., Domínguez-Fabián, I. and Devesa-Carpio, J. E. (2006). Subjective Economic Risk to beneficiaries in Notional Defined Contribution Accounts (NDC's). The Journal of Risk and Insurance, 73 (3), 489-515.

Vidal-Meliá, C., Ventura-Marco, M. and Pérez-Salamero González, J.M. (2018). Social insurance accounting for a notional defined contribution scheme combining retirement and long-term care benefits. Sustainability, 10, 2832.

Wiener, M. and Stokoe, P. (2018). Discussing accrued-to-date liabilities. International Social Security Review, 71(3): 27-48.

Yermo, J. and Severinson, C. (2010). "The Impact of the Financial Crisis on Defined Benefit Plans and the Need for Counter-Cyclical Funding Regulations", OECD Working Papers on Finance, Insurance and Private Pensions, No. 3, OECD Publishing. doi: 10.1787/5km91p3jszxw-en.

\section{Appendix 1: Technical appendix}

This Technical appendix shows the main formulas used to transform Table 29 into an ABS and compile its associated income statement (IS).

1.-The contribution asset $\left(C A_{t}^{S}\right)$ :

$$
C A_{t}^{S}=T D_{t}^{S} \cdot C_{t}^{S}=\left(A_{p}^{S}-A_{c}^{S}\right) \cdot C_{t}^{S} .
$$

where $C_{t}^{S}$ is the income from ordinary contributions, $T D_{t}^{S}$ is the turnover duration, $A_{p}^{S}$ is the weighted average age of the pensioners, and $A_{c}^{S}$ is the weighted average age of the contributors.

2.-'The system's solvency indicator $\left(S I_{t}^{S}\right)$ :

$$
\left.S I_{t}^{S}=\frac{\left(B F_{t}^{S}+C A_{t}^{S}+P C A_{t}^{S}\right)}{(\overbrace{V_{t}^{c}+V_{t}^{p}+{ }^{N C R} V_{t}^{c}+{ }^{N C R} V_{t}^{p}}^{V^{S}=\text { Pension obligations }}+F L_{t}^{S}}\right)
$$

where $B F_{t}^{S}$ is the buffer fund, $P C A_{t}^{S}$ is the public contribution asset, $V_{t}^{c}$ is the liability to contributors, $V_{t}^{p}$ is the liability to pensioners, ${ }^{N C R} V_{t}^{c}$ is the liability to contributors due to non-contributory rights (NCR), ${ }^{N C R} V_{t}^{p}$ is the liability to pensioners for NCRs, and $F L_{t}^{S}$ is the amount of the financial loans.

3.-The required growth rate $\left(G_{t}^{*}\right)$ : 


$$
\left[B F_{t}^{S}+C A_{t}^{S}+P C A_{t}^{S}\right] \underset{\sim}{G_{t}^{*}}\left[V_{t}^{c}+V_{t}^{p}+{ }^{N C R} V_{t}^{c}+{ }^{N C R} V_{t}^{p}+F L_{t}^{S}\right]
$$

4.-The change in net worth can be detailed as follows:

$$
\begin{gathered}
\begin{array}{c}
\delta N W_{t}^{S}=N W_{t}^{S}-N W_{t-1}^{S} \\
\text { Changes in net worth } \\
=
\end{array} \\
\overbrace{\left(\frac{\overbrace{A_{t}^{S}-A_{t-1}^{S}}^{\text {Assets }})-\left(A_{t}^{S}-\delta V_{t}^{S}\right.}{\left.V_{t}^{S}-V_{t-1}^{S}\right)}\right)}^{\text {Changes }} \\
\underbrace{\text { Changes }}_{\text {Chabilities }} \\
\underbrace{\delta B F_{t}^{S}}_{\text {Fund asset }}+\underbrace{\delta C A_{t}^{S}}_{\text {Contribution asset }}-\overbrace{\delta V_{t}^{S}}^{\text {Liabilities }}
\end{gathered}
$$

5.- Change in the fund/financial asset:

$$
\delta B F_{t}^{S}=C_{t}^{S}+{ }^{N C R} S C_{t}^{S}-P T_{t}^{S}-O O_{t}^{S}+D_{t}^{S}+\delta F L_{t}^{S}
$$

where ${ }^{N C R} S C_{t}^{S}$ is the income from sponsor contributions for NCRs, $P T_{t}^{S}$ is total pension disbursements, $O O_{t}^{S}$ is other outflows, $D_{t}^{S}$ is the net return on funded capital, and $\delta F L_{t}^{S}$ is the value of the change in financial loans.

6.-Change in the contribution asset:

$$
\begin{aligned}
& \delta C A_{t}^{S}=C A_{t}^{S}-C A_{t-1}^{S}=\overbrace{\delta C_{t}^{S}}^{\text {Revenue effect }}+\underbrace{\delta T D_{t}^{S}}_{\begin{array}{c}
\text { Turnover duration } \\
\text { effect }
\end{array}} \\
& = \\
& \overbrace{\left(\left(C_{t}^{S}-C_{t-1}^{S}\right) \cdot \frac{\left(T D_{t-1}^{S}+T D_{t}^{S}\right)}{2}\right)}^{\delta C_{t}^{S}}+(\underbrace{\frac{\left(C_{t}^{S}+C_{t-1}^{S}\right)}{2} \cdot\left(T D_{t}^{S}-T D_{t-1}^{S}\right)}_{\delta T D_{t}^{S}})
\end{aligned}
$$

7.-Change in pension liability:

$$
\delta V_{t}^{S}=\overbrace{C_{t}^{* S}}^{\text {Row } 2}-\underbrace{P T_{t}^{S}}_{\text {Row } 4}+\overbrace{\delta A c_{t}^{S}}^{\text {Row } 3}+\underbrace{\delta S s_{t}^{S}}_{\text {Row } 7}+\overbrace{\delta R_{t}^{S}}^{\text {Row } 8}+\underbrace{\delta O v_{t}^{S}}_{\text {Row } 9}
$$

where $C_{t}^{* S}$ is employer and employee actual social contributions plus the property income earned or imputed in the schemes, $\delta A c_{t}^{S}$ is other (actuarial) changes of pension entitlements in social security pension schemes, $\delta S s_{t}^{S}$ is the change in entitlements due to negotiated changes in the scheme's structure, $\delta R_{t}^{S}$ is changes in entitlements due to revaluations, and $\delta O v_{t}^{S}$ is changes in entitlements due to other changes in volume. 
8.-Change in financial liabilities:

$$
\delta F L_{t}^{S}=N L_{t}^{S}+P L_{t}^{S}
$$

where $\delta F L_{t}^{S}$ is the value of the change in financial loans, $N L_{t}^{S}$ is loans for the period, and $P L_{t}^{S}$ is the payment of loans for the period.

9.-The pension liability is estimated based on the figure shown in Table $4\left(V_{t}^{P_{-} T 29}\right)$, taking into account the change $(\Delta d r)$ between the new discount rate $(G)$ and the original value used for estimating pension entitlements $(r)$, and the change $(\Delta i r)$ between the new indexation rate of pensions in payment $\left(\lambda^{*}\right)$ and the original value $(\lambda)$. It can be expressed as:

$$
\left.\widehat{V}_{t}^{S}\right|_{\substack{d r=G \% \\ i r=\lambda^{*} \%}}=\overbrace{V_{t}^{S_{T 29}}+\left.\Delta d r \cdot \frac{\partial V_{t}^{S_{T 29}}}{\partial d r}\right|_{d r=r \%}}^{\left.\widehat{V}_{t}^{S}\right|_{d r=G \%}}+\left.\Delta i r \cdot \frac{\left.\partial \widehat{V}_{t}^{S}\right|_{d r=G \%}}{\partial i r}\right|_{i r=\lambda \%}
$$

where $\Delta d r=G \%-r \%$ and $\Delta i r=\lambda^{*} \%-\lambda \%$.

A two-stage numerical derivation procedure and a sensitivity analysis are applied from a polynomial adjustment of the values published by the INE for each of the different scenarios taken from Table 29. 
Appendix 2: Main results for the period 2014-2015.

Table A1: ABS and IS for 2015. Social Security scheme. Spain. Unit: EUR million.

\begin{tabular}{|c|c|c|c|}
\hline \multicolumn{4}{|c|}{ Income Statement for 2015} \\
\hline ASSETS 1-1-2015 & $3,102,315$ & $3,423,538$ & LIABILITIES 1-1-2015 \\
\hline Financial assets & 41,635 & 0 & Financial liabilities \\
\hline Contribution assets & $3,060,680$ & $3,423,538$ & Pension entitlements \\
\hline Change in fund assets & $-9,150$ & $\mathbf{0}$ & Change in financial liabilities \\
\hline $\begin{array}{c}\text { Value of change in financial } \\
\text { loans }\end{array}$ & 0 & 202,034 & Change in pension entitlements \\
\hline Pension contributions & 94,746 & 240,195 & Social contributions \\
\hline $\begin{array}{l}\text { Sponsor contributions for } \\
\text { NCRs }\end{array}$ & 19,644 & 67,592 & Employer contributions \\
\hline Pension disbursements & $-116,006$ & 27,154 & Household contributions \\
\hline Net return on funded capital & 1,083 & 145,449 & $\begin{array}{c}\text { Household social } \\
\text { contribution supplements }\end{array}$ \\
\hline Other outflows & $-8,617$ & 49,502 & $\begin{array}{l}\text { Other (actuarial) changes } \\
\text { in pension entitlements }\end{array}$ \\
\hline $\begin{array}{c}\text { Changes in } \\
\text { contribution assets }\end{array}$ & 26,617 & $-116,006$ & Payment of pension benefits \\
\hline $\begin{array}{l}\text { Value of change in } \\
\text { contribution revenue }\end{array}$ & 36,332 & 28,343 & $\begin{array}{c}\text { Changes in entitlements due to } \\
\text { revaluations and other }\end{array}$ \\
\hline Value of change in TD & $-9,715$ & 28,343 & $\begin{array}{c}\text { Changes in entitlements } \\
\text { due to revaluations }\end{array}$ \\
\hline $\begin{array}{c}\text { Total change } \\
\text { in system assets }\end{array}$ & 17,467 & 202,034 & $\begin{array}{c}\text { Total change } \\
\text { in system liabilities }\end{array}$ \\
\hline ACTUARIAL LOSSES & 184,567 & & \\
\hline \multicolumn{4}{|c|}{ Actuarial Balance Sheet at 31-12-2015 } \\
\hline ASSETS 31-12-2015 & $3,119,782$ & $3,625,572$ & LIABILITIES 31-12-2015 \\
\hline Financial assets & 32,485 & 0 & Financial liabilities \\
\hline Contribution assets & $3,087,297$ & $3,625,572$ & Pension entitlements \\
\hline $\begin{array}{l}\text { ACCUMULATED } \\
\text { SHORTFALL } \\
\end{array}$ & 321,223 & & \\
\hline ACTUARIAL LOSSES & 184,567 & & \\
\hline TOTAL DEBIT SIDE & $3,625,572$ & $3,625,572$ & TOTAL CREDIT SIDE \\
\hline
\end{tabular}




\begin{tabular}{|c|c|c|c|c|}
\hline \multicolumn{5}{|c|}{ Table A2: ABS and IS indicators for 2015 and 2014} \\
\hline $\begin{array}{l}\text { Row } \\
\text { No. }\end{array}$ & Items & Units & 2015 & 2014 \\
\hline 1 & $A_{p}^{S}$ & \multirow{3}{*}{ Years } & 71.19 & 71.11 \\
\hline 2 & $A_{C}^{S}$ & & 44.14 & 43.97 \\
\hline 3 & $T D_{t}^{S}$ & & 27.05 & 27.13 \\
\hline 4 & $\frac{C t_{t}^{S}}{P s_{t}}$ & Ratio & 2.02 & 1.98 \\
\hline 5 & $P S I_{t}^{S}$ & \multirow{2}{*}{$\begin{array}{c}\text { Between } \\
0 \text { and } 1\end{array}$} & 0.7158 & 0.7505 \\
\hline 6 & $S I_{t}^{S}$ & & 0.8605 & 0.9062 \\
\hline 7 & $\frac{L_{t}^{S}}{G D P_{t}}$ & \multirow{7}{*}{$\%$} & $17.13 \%$ & \\
\hline 8 & $\frac{A d_{t}^{S}+L_{t}^{S}}{G D P_{t}}$ & & $46.94 \%$ & $31.12 \%$ \\
\hline 9 & $\frac{V_{t}^{S}}{G D P_{t}}$ & & $336.45 \%$ & $331.69 \%$ \\
\hline 10 & $G_{t}^{*}$ & & $3.05 \%$ & $2.82 \%$ \\
\hline 11 & Gap in $G_{t}^{*}$ & & $0.85 \%$ & $0.57 \%$ \\
\hline 12 & $G_{t}^{* *}$ & & $3.95 \%$ & $3.78 \%$ \\
\hline 13 & Gap in $G_{t}^{* *}$ & & $1.74 \%$ & $1.52 \%$ \\
\hline & & Oxwel & ation & \\
\hline
\end{tabular}

